\title{
43. LEG 80 SHIPBOARD ORGANIC GEOCHEMISTRY ${ }^{1}$
}

\author{
Douglas W. Waples, Mobil Research and Development Corporation, Dallas \\ and \\ Robert Cunningham, Exxon Production Research Company, Houston ${ }^{2}$
}

\begin{abstract}
The four sites drilled on the Irish continental margin (Goban Spur) yielded sediments ranging in age from Holocene to Barremian. Most of the sediments were deposited in well oxygenated waters, and the small amounts of organic matter they contain are highly oxidized.

During a few time intervals from the Cenomanian to earliest Turonian, however, the oxygen content of the bottom waters reached very low levels, resulting in the deposition of homogeneous or laminated black sediments containing from 0.5 to $11 \%$ total organic carbon (TOC). The original organic matter was of mixed marine and terrestrial origin. The oxidizing-reducing cycles represented by interbedded black and light sediments are probably a result of changes in both circulation and productivity. The black sediments at Sites 550,551 , and 549 were probably deposited near the lower end, middle, and upper end, respectively, of an expanded oxygen-minimum layer.

The oil and gas source potential of the laminated black sediments is very good to excellent. The organic-carbon-lean sediments deposited under oxidizing conditions have no oil or gas source potential. The thermal maturity of all sediments is low.
\end{abstract}

\section{INTRODUCTION}

The postrift sediments recovered at the four sites drilled on Leg 80 comprise mainly nannofossil oozes, chalks, and marly chalks of Late Cretaceous and Tertiary age. Where cored, the Pleistocene and Holocene sections consist of alternating nannofossil oozes and calcareous silts and clays.

Some variation from site to site is apparent in the synand early postrift sediments (Barremian-Albian), because water depths differed appreciably among the sites at those times. Shallow-shelf sediments of Barremian to Albian age were recovered at Site 549, whereas the Albian sediments at Site 550 represent slope facies. Slightly metamorphosed prerift sediments (Hercynian) were recovered at two sites, but they were not studied in detail.

The shipboard geochemical analyses performed routinely on the Leg 80 sediments included carbonate content analysis (607 samples), total organic carbon (TOC) and total nitrogen analysis (504 samples), and Rock-Eval pyrolysis (165 samples). Data for the individual sites are presented in Tables 1 to 4 .

\section{ANALYTICAL PROCEDURES}

All the methods employed are standard shipboard procedures. Carbonate content was measured by treating $1.00 \mathrm{~g}$ of dried $\left(40^{\circ} \mathrm{C}\right)$, crushed sediment with $5 \mathrm{ml}$ of concentrated $\mathrm{HCl}$ in a sealed vessel (carbonate bomb) equipped with a calibrated pressure gauge (Bode, 1973). The carbonate-free residues were then washed three times with deionized water through a suction filter, dried at $40^{\circ} \mathrm{C}$, and burned at $1050^{\circ} \mathrm{C}$ in a Hewlett-Packard Model 185B CHN analyzer. The total organic carbon and total nitrogen contents of the carbonate-free residue were determined by comparison with a shipboard standard. The TOC and to-

\footnotetext{
${ }^{1}$ Graciansky, P. C. de, Poag, C. W., et al., Init. Repts. DSDP, 80: Washington (U.S. Govt, Printing Office).

2 Addresses: (Waples, present address) 1717 Place One Lane, Garland, TX 75042; (Cunningham) Exxon Production Research Company, P.O. Box 2189, Houston, TX 77001.
}

tal nitrogen contents of the whole rock were then calculated by correcting for carbonate removal.

A few samples from Site 551 were analyzed at the Mobil Field Research Laboratory. Carbonate content was measured by weight loss upon acidification with concentrated $\mathrm{HCl}$, and TOC values were measured by burning the carbonate-free residue in a LECO furnace.

Rock-Eval pyrolysis of whole rock samples was carried out as described by Espitalié et al. (1977). The $\mathrm{S}_{1}, \mathrm{~S}_{2}$, and $\mathrm{S}_{3}$ peaks were interpreted after Clementz et al. (1979).

\section{RESULTS}

\section{Site 548}

The samples from all lithologic units at Site 548 were lean in organic carbon: the maximum TOC value is $0.78 \%$, and the minimum values are less than $0.1 \%$. With few exceptions, atomic $\mathrm{C} / \mathrm{N}$ ratios range from 5 to 12 , but they probably reflect a dominant contribution of inorganic nitrogen (Waples, "Nitrogen," this volume).

A plot of TOC versus burial depth (Fig. 1) shows that there is a pronounced decrease in TOC with increasing depth of burial. Within a given lithologic unit, however, TOC is inversely related to $\mathrm{CaCO}_{3}$ content (Fig. 2).

Hydrogen and oxygen indices derived from Rock-Eval pyrolysis (Table 1) indicate very low hydrocarbon source potential in all lithologic units. Maximum pyrolysis temperatures $\left(T_{\max }\right)$ indicate that the sediments in the section are too thermally immature for hydrocarbon generation (Table 1).

\section{Units 1 and 2}

Units 1 and 2 appear in Hole 548 from Core 1 through Core 15 , Section 6 . The units consist of alternating marly calcareous oozes and nannofossil oozes and have the highest TOC values at Site 548. The more argillaceous sediments, which were deposited as turbidites, are the most enriched in organic carbon, averaging about $0.6 \%$ 


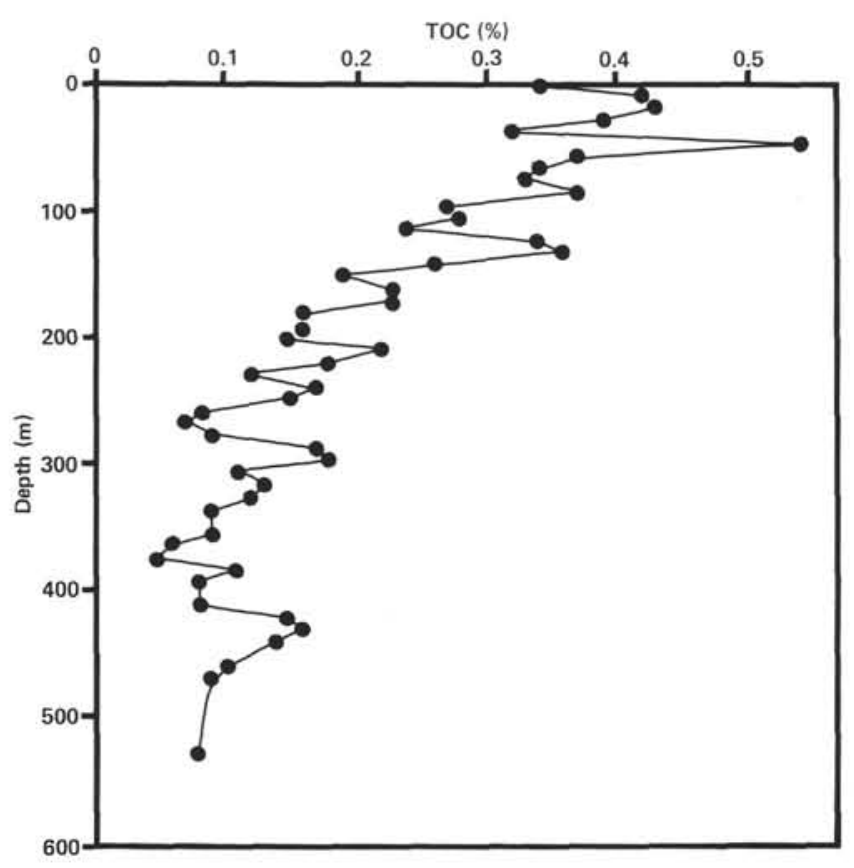

Figure 1. TOC versus depth for Site 548. Values are averaged over intervals of $9.5 \mathrm{~m}$ (one standard core length).

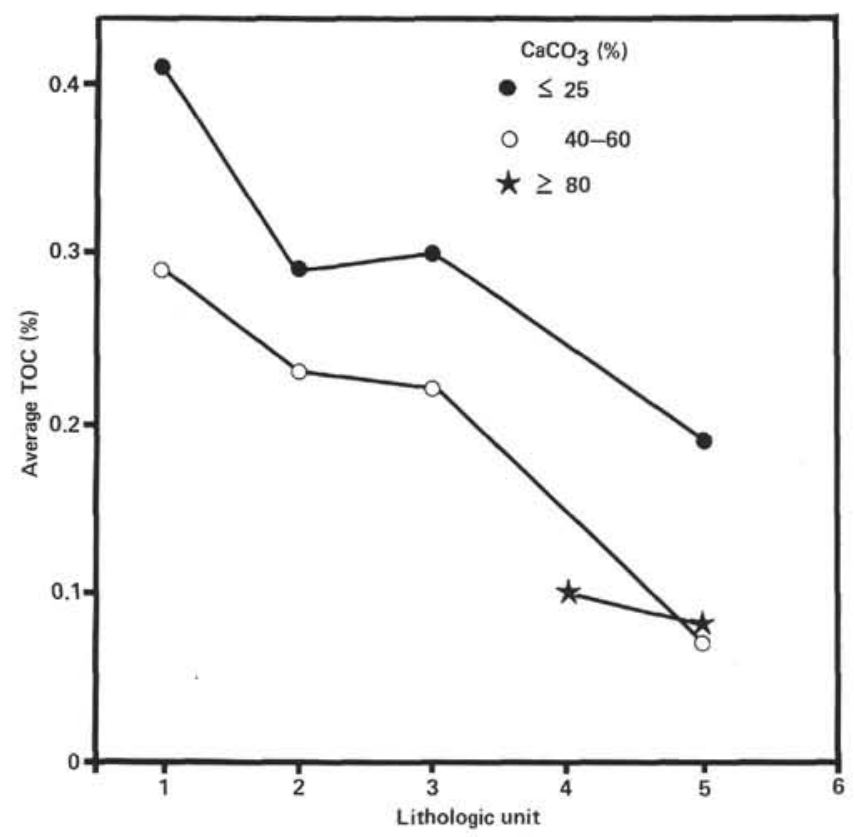

Figure 2. Average TOC values by lithologic unit for sediments of various $\mathrm{CaCO}_{3}$ contents, Site 548 .

TOC. The nannofossil oozes, which were deposited much more slowly, have lower TOC values.

\section{Unit 3}

Unit 3 appears in Hole 548 from Cores 16 to 35 and in Hole 548A from Core 1 to Core 11, Section 3, $125 \mathrm{~cm}$. The TOC values decrease and carbonate contents increase with depth. Sparse Rock-Eval data suggest that the organic matter is similar to that of the overlying units.

\section{Unit 4}

Unit 4 appears in Hole 548A from Core 11, Section $3,125 \mathrm{~cm}$ to Core 22, Section $6,15 \mathrm{~cm}$. It is made up of calcareous oozes that have very high carbonate contents and low TOC values. Because of the low TOC values, the few Rock-Eval analyses are not very reliable.

\section{Unit 5}

Unit 5 appears in Hole 548A from Core 22, Section $6,15 \mathrm{~cm}$ to Core 28 , Section $6,35 \mathrm{~cm}$. The unit's carbonate contents are variable but in general much lower than in the Unit 4 sediments. The TOC values are in general slightly higher. The single Rock-Eval pyrolysis indicated no hydrocarbon source potential.

\section{Unit 6}

Unit 6 appears in Hole 548A from Core 28, Section 6, $35 \mathrm{~cm}$ through Core 35 . The sediments are nearly pure chalks and have very low TOC values. No Rock-Eval analyses were attempted.

\section{Site 549}

Syn- and postrift sediments of Barremian to Pleistocene age were recovered from Site 549. As one moves uphole the sediments change from inner sublittoral to pelagic. In addition, a slightly metamorphosed sandstone, presumably of pre-rift Hercynian age, was recovered from the bottom of the hole.

Site 549 is much more heterogeneous lithologically than Site 548 , a difference that is clearly displayed in the geochemistry of the sediments. The monotonic decrease in organic carbon content with increasing depth of burial observed at Site 548 is not very evident at Site 549, although in the upper $30 \mathrm{~m}$ a slight decrease does occur (Table 2 and Fig. 3).

The hydrogen and oxygen indices derived from RockEval pyrolysis (Table 2) are plotted on a Van Krevelen diagram in Figure 4. The maximum pyrolysis temperatures $\left(T_{\max }\right)$ are reported in Table 2.

\section{Unit 1}

Unit 1 appears in Hole 549A from Cores 1 to 3 and consists of Quaternary sediments that, like those at Site 548 , show relatively high TOC values in comparison to Tertiary sediments. One sample (Core 3, Section 2, 43$44 \mathrm{~cm})$ has a TOC value $(0.66 \%)$ similar to the values observed in several samples from the Unit 1 turbidites at Site 548. The carbonate contents are variable and inversely correlated with the TOC values (Table 2 ). The Rock-Eval analyses indicate very low oil source potential and the presence of a refractory type of organic matter in these sediments.

\section{Unit 2}

Unit 2 appears in Hole 549A from Cores 4 to 42 and in Hole 549 from Core 2 to Core 10, Section 2, $65 \mathrm{~cm}$. It consists of nannofossil chalks that contain very little noncalcareous material and have very low TOC values. The Rock-Eval analyses are not reliable because of the low 
Table 1. Organic geochemical data for Site 548.

\begin{tabular}{|c|c|c|c|c|c|c|c|}
\hline & & & & & & & \\
\hline $\begin{array}{l}\text { Lithologic } \\
\text { unit }\end{array}$ & Age & $\begin{array}{c}\text { Sample } \\
\text { (interval in } \mathrm{cm} \text { ) }\end{array}$ & $\begin{array}{c}\mathrm{CaCO}_{3} \\
(\%)\end{array}$ & $\begin{array}{l}\text { TOC } \\
(\%)\end{array}$ & $\underset{(\%)}{N}$ & $\begin{array}{l}\text { Atomic } \\
\mathrm{C} / \mathrm{N}\end{array}$ & $\begin{array}{l}T_{\max } \\
\left({ }^{\circ} \mathrm{C}\right)\end{array}$ \\
\hline 1 & Holocene & $548-1-1(9-10)$ & 48 & 0.24 & 0.034 & 8.4 & \\
\hline & to & $-1-1(100-102)$ & 22 & 0.37 & 0.055 & 7.8 & \\
\hline & Pleistocene & $-1-2(100-102)$ & 17 & 0.42 & 0.043 & 11.3 & 423 \\
\hline & & $-2-1(43-44)$ & 14 & 0.73 & 0.084 & 11.7 & \\
\hline & & $-2-2(43-44)$ & 19 & 0.41 & 0.061 & 7.8 & 416 \\
\hline & & $-2-3(43-44)$ & 19 & 0.36 & 0.057 & 8.6 & \\
\hline & & $-2-4(35-36)$ & 23 & 0.32 & 0.048 & 7.7 & \\
\hline & & $-2-5(35-36)$ & 19 & 0.31 & 0.061 & 6.0 & \\
\hline & & $-2-6(35-36)$ & 20 & 0.36 & 0.060 & 8.1 & \\
\hline & & $-3-1(36-37)$ & 23 & 0.32 & 0.058 & 7.5 & \\
\hline & & $-3-1(57-58)$ & 47 & 0.27 & 0.031 & 10.1 & 410 \\
\hline & & $-3-2(57-58)$ & 24 & 0.49 & 0.062 & 9.2 & \\
\hline & & $-3-3(57-58)$ & 23 & 0.39 & 0.055 & 9.3 & \\
\hline & & $-3-4(57-58)$ & 22 & 0.33 & 0.051 & 8.6 & \\
\hline & & $-3-5(57-58)$ & 15 & 0.43 & 0.050 & 9.8 & 420 \\
\hline & & $-3-6(57-58)$ & 18 & 0.33 & 0.048 & 9.5 & \\
\hline & & $-4-1(77-78)$ & 27 & 0.42 & 0.068 & 8.4 & \\
\hline & & $-4-2(77-78)$ & 31 & 0.31 & 0.049 & 7,3 & 387 \\
\hline & & $-4-3(77-78)$ & 18. & 0.46 & 0.061 & 8.8 & \\
\hline & & $-4-4(77-78)$ & 21 & 0.42 & 0.068 & 8.3 & \\
\hline & & $-4-5(77-78)$ & 30 & 0.26 & 0.034 & 8.8 & 422 \\
\hline & & $-4-6(46-47)$ & 18 & 0.48 & 0.073 & 8.9 & \\
\hline & & $-5-1(75-76)$ & 36 & 0.25 & 0.039 & 7.4 & 388 \\
\hline & & $-5-2(51-52)$ & 42 & 0.22 & 0.029 & 8.9 & 401 \\
\hline & & $-5-3(51-52)$ & 15 & 0.48 & 0.065 & 10.2 & \\
\hline & & $-5-4(51-52)$ & 18 & 0.41 & 0.051 & 10.7 & \\
\hline & & $-5-5(51-52)$ & 25 & 0.30 & 0.055 & 6.4 & \\
\hline & & $-5.6(51-52)$ & 16 & 0.28 & 0.057 & 5.6 & \\
\hline & & $-6-1(68-69)$ & 33 & 0.29 & 0.037 & 9.3 & \\
\hline & & $-6-2(32-33)$ & 36 & 0.36 & 0.048 & 9.0 & 408 \\
\hline & & $-6-3(30-31)$ & 29 & 0.59 & 0.055 & 12.6 & 413 \\
\hline & & $-6-4(30-31)$ & 29 & 0.63 & 0.073 & 11.6 & \\
\hline & & $-6-5(30-31)$ & 16 & 0.57 & 0.058 & 11.4 & 417 \\
\hline & & $-6-6(30-31)$ & 12 & 0.78 & 0.059 & 17.8 & 420 \\
\hline & & $-7-1(86-87)$ & 24 & 0.73 & 0.054 & 18.3 & \\
\hline & & $-7.2(86-87)$ & 19 & 0.29 & 0.037 & 9.1 & \\
\hline & & $-7-3(86-87)$ & 17 & 0.46 & 0.061 & 8.8 & \\
\hline & & $-7-4(86-87)$ & 33 & 0.25 & 0.038 & 7.8 & 405 \\
\hline & & $-7-5(35-36)$ & 28 & 0.26 & 0.035 & 8.6 & \\
\hline & & $-7-6(51-52)$ & 59 & 0.20 & 0.027 & 8.7 & 410 \\
\hline & & $-8-1(91-92)$ & 56 & 0.33 & 0.031 & 12.1 & 410 \\
\hline & & $-8-2(91-92)$ & 49 & 0.38 & 0.040 & 10.9 & 407 \\
\hline & & $-8-3(91-92)$ & 51 & 0.33 & 0.044 & 8.8 & \\
\hline & & $-8-4(91-92)$ & 47 & 0.38 & 0.052 & 9.7 & \\
\hline & & $-8-5(91-92)$ & 48 & 0.30 & 0.039 & 9.1 & 404 \\
\hline & & $-8-6(91-92)$ & 50 & & & & \\
\hline 2 & early & $-9-2(45-46)$ & 51 & 0.63 & 0.032 & 22.9 & 394 \\
\hline & Pleistocene & $-10-2(45-46)$ & 37 & 0.40 & 0.050 & 9.5 & 403 \\
\hline & to late & $-10-3(45-46)$ & 37 & 0.22 & 0.027 & 11.0 & \\
\hline & Pliocene & $-10-4(45-46)$ & 35 & 0.27 & 0.038 & 9.6 & 384 \\
\hline & & $-10-5(45-46)$ & 40 & 0.21 & 0.044 & 6.5 & 383 \\
\hline & & $-10-6(45-46)$ & 47 & 0.26 & 0.046 & 7.7 & \\
\hline & & $-11-1(75-76)$ & 28 & 0.44 & 0.060 & 9.7 & \\
\hline & & $-11-2(75-76)$ & 22 & 0.37 & 0.081 & 5.3 & 396 \\
\hline & & $-11-3(75-76)$ & 13 & 0.32 & 0.051 & 8.3 & \\
\hline & & $-11-4(75-76)$ & 8 & 0.24 & 0.046 & 6.1 & \\
\hline & & $-11-5(75-76)$ & 29 & 0.50 & 0.052 & 12.6 & 416 \\
\hline & & $-12-2(37-38)$ & 18 & 0.30 & 0.053 & 6.6 & 397 \\
\hline & & $-13-1(8-9)$ & 14 & 0.27 & 0.041 & 7.5 & \\
\hline & & $-13-2(8-9)$ & 44 & 0.27 & 0.043 & 7.4 & 376 \\
\hline & & $-13-3(8-9)$ & 49 & 0.16 & 0.032 & 7.0 & 385 \\
\hline & & $-13-4(8-9)$ & 42 & 0.23 & 0.034 & 9.1 & \\
\hline & & $-13-5(8-9)$ & 18 & 0.47 & 0.062 & 8.8 & \\
\hline & & $-13-6(8-9)$ & 38 & 0.27 & 0.041 & 8.9 & \\
\hline & & $-14-2(19-20)$ & 22 & 0.21 & 0.054 & 4.6 & 393 \\
\hline & & $-15-1(65-66)$ & 39 & 0.40 & 0.046 & 11.7 & \\
\hline & & $-15-2(65-66)$ & 51 & 0.24 & 0.032 & 8.6 & 395 \\
\hline & & $-15-3(65-66)$ & 22 & 0.28 & 0.045 & 7.3 & \\
\hline & & $-15-4(65-66)$ & 48 & 0.33 & 0.066 & 6.8 & 381 \\
\hline & & $-15-5(65-66)$ & 46 & 0.24 & 0.044 & 7.2 & \\
\hline & & $-15-6(65-66)$ & 41 & 0.16 & 0.027 & 8.0 & \\
\hline 3 & late & $-16-1(46-47)$ & 46 & 0.28 & 0.051 & 7.3 & \\
\hline & Pliocene & $-16-2(46-47)$ & 53 & 0.21 & 0.042 & 5.9 & 364 \\
\hline & to late & $-16-3(46-47)$ & 11 & 0.26 & 0.052 & 5.7 & 390 \\
\hline & Miocene & $-16-4(46-47)$ & 47 & 0.26 & 0.046 & 7.6 & \\
\hline & & $-16-5(46-47)$ & 12 & 0.17 & 0.038 & 5.1 & \\
\hline & & $-16-6(46-47)$ & 13 & 0.23 & 0.051 & 6.2 & \\
\hline & & $-17-1(63-64)$ & 47 & 0.30 & 0.050 & 8.1 & \\
\hline & & $-17-2(63-64)$ & 21 & 0.27 & 0.040 & 7.9 & 386 \\
\hline & & $-17-3(63-64)$ & 37 & 0.41 & 0.062 & 9.1 & \\
\hline & & $-17-4(63-64)$ & 22 & 0.36 & 0.060 & 7.9 & \\
\hline & & $-17-5(63-64)$ & 19 & 0.34 & 0.049 & 8.1 & \\
\hline & & $-18-1(3-5)$ & 41 & 0.32 & 0.047 & 9.5 & \\
\hline & & $-18-2(3-5)$ & 20 & 0.36 & 0.056 & 7.5 & \\
\hline & & $-18-3(3-5)$ & 48 & 0.46 & 0.073 & 8.4 & \\
\hline & & $-18-4(3-5)$ & 9 & 0.35 & 0.063 & 7.4 & \\
\hline & & $-19-2(88-89)$ & 40 & 0.31 & 0.042 & 8.5 & \\
\hline & & $-19-3(88-89)$ & 17 & & & & \\
\hline & & $-20-1(49-50)$ & 22 & 0.35 & 0.067 & 7.1 & \\
\hline
\end{tabular}


D. W. WAPLES, R. CUNNINGHAM

Table 1. (Continued).

\begin{tabular}{|c|c|c|c|c|c|c|c|c|c|}
\hline \multirow[b]{2}{*}{$\begin{array}{l}\text { Lithologic } \\
\text { unit }\end{array}$} & \multirow[b]{2}{*}{ Age } & \multirow[b]{2}{*}{$\begin{array}{c}\text { Sample } \\
\text { (interval in } \mathrm{cm} \text { ) }\end{array}$} & & & & & & ock-Ev: & \\
\hline & & & $\underset{(\%)}{\mathrm{CaCO}_{3}}$ & $\begin{array}{l}\text { TOC } \\
(\%)\end{array}$ & $\begin{array}{c}\mathrm{N} \\
\left(\%_{0}\right)\end{array}$ & $\begin{array}{c}\text { Atomic } \\
\mathrm{C} / \mathrm{N}\end{array}$ & $\begin{array}{l}T_{\max } \\
\left({ }^{\circ} \mathrm{C}\right)\end{array}$ & $\begin{array}{l}\mathrm{H}- \\
\text { index }\end{array}$ & $\begin{array}{l}\text { O- } \\
\text { index }\end{array}$ \\
\hline 3 (Cont.) & late & $-20-2(49-50)$ & 62 & 0.15 & 0.031 & 5.6 & & & \\
\hline & Pliocene & $-20-3(49-50)$ & 29 & 0.41 & 0.066 & 8.4 & 378 & 44 & 61 \\
\hline & to late & $-21-1(75-76)$ & 49 & 0.21 & 0.034 & 8.4 & & & \\
\hline & Miocene & $-21-2(75-76)$ & 51 & 0.20 & 0.032 & 7.0 & & & \\
\hline & & $-21-3(75-76)$ & 40 & 0.21 & 0.037 & 7.6 & & & \\
\hline & & $-22-1(120-121)$ & 40 & 0,16 & 0.030 & 7.4 & & & \\
\hline & & $-22-1(120-121)$ & 54 & 0.19 & 0.034 & 6.5 & & & \\
\hline & & $-22-3(120-121)$ & 49 & 0.20 & 0.037 & 7.4 & & & \\
\hline & & $-23-2(27-28)$ & 59 & 0.20 & 0.030 & 7.6 & & & \\
\hline & & $-24-2(66-67)$ & 42 & 0.21 & 0.035 & 7.0 & 382 & 124 & 129 \\
\hline & & $-25-1(24-25)$ & 54 & 0.23 & 0.037 & 8.6 & & & \\
\hline & & $-25-2(24-25)$ & 51 & 0.25 & 0.036 & 7.9 & & & \\
\hline & & $-26-2(89-90)$ & 53 & 0.20 & 0.031 & 7.6 & & & \\
\hline & & $-27-2(36-37)$ & 58 & 0.26 & 0.035 & 8.7 & & & \\
\hline & & $-28-2(84-85)$ & 53 & 0.13 & 0.020 & 8.0 & & & \\
\hline & & $-28-3(84-85)$ & 54 & 0.18 & 0.028 & 7.4 & & & \\
\hline & & $-29.1(82-83)$ & 61 & 0.23 & 0.036 & 8.3 & & & \\
\hline & & $-29-2(82-83)$ & 62 & 0.20 & 0.031 & 7.5 & & & \\
\hline & & $-29-3(82-83)$ & 70 & 0.08 & 0.015 & 5.7 & & & \\
\hline & & $-30-2(82-83)$ & 62 & 0.17 & 0.027 & 7.4 & & & \\
\hline & & $-30-3(82-83)$ & 67 & 0.12 & 0.020 & 7.0 & & & \\
\hline & & $-31-2(82-83)$ & 61 & 0.15 & 0.023 & 7.8 & & & \\
\hline & & $-31-3(82-83)$ & 56 & 0.18 & 0.052 & 4.8 & & & \\
\hline & & $-32-2(82-83)$ & 67 & 0.14 & 0.021 & 7.9 & & & \\
\hline & & $-33-2(58-59)$ & 61 & 0.15 & 0.023 & 7.8 & & & \\
\hline & & $-34-2(41-42)$ & 53 & 0.27 & 0.037 & 8.3 & & & \\
\hline & & $-35-1(51-52)$ & 53 & 0.16 & 0.023 & 7.8 & & & \\
\hline & & $548 \mathrm{~A}-2-2(100-101)$ & 54 & 0.18 & 0.024 & 8.9 & & & \\
\hline & & $-3-2(83-84)$ & 60 & 0.14 & 0.022 & 7.5 & & & \\
\hline & & $-3-5(83-84)$ & 38 & 0.09 & 0.019 & 5.8 & & & \\
\hline & & $-4-2(55-56)$ & 62 & 0.14 & 0.018 & 9.2 & & & \\
\hline & & $-4-5(55-56)$ & 54 & 0.20 & 0.028 & 8.2 & & & \\
\hline & & $-5-2(30-31)$ & 66 & 0.19 & 0.024 & 9.4 & 388 & 95 & 105 \\
\hline & & $-5-6(30-31)$ & 46 & 0.10 & 0.016 & 7.0 & & & \\
\hline & & $-6-2(147-148)$ & 67 & 0.08 & 0.012 & 7.6 & & & \\
\hline & & $-7-2(45-46)$ & 31 & 0.07 & 0.010 & 7.5 & & & \\
\hline & & $-8-2(64-65)$ & 58 & 0.09 & 0.016 & 6.9 & & & \\
\hline & & $-8-5(45-46)$ & 5s & & & & & & \\
\hline & & $-9-2(85-86)$ & 46 & 0.16 & 0.023 & 8.0 & & & \\
\hline & & $-9-5(87-88)$ & 50 & 0.17 & 0.019 & 10.4 & & & \\
\hline & & $-10-2(75-76)$ & 51 & 0.18 & 0.021 & 10.1 & 390 & 128 & 127 \\
\hline & & $-10-5(75-76)$ & 54 & & & & & & \\
\hline & & $-11-2(43-44)$ & 62 & 0.11 & 0.024 & 9.9 & & & \\
\hline 4 & middle & $-11-5(43-44)$ & 90 & 0.10 & 0.013 & 10.3 & & & \\
\hline & Miocene & $-12-2(68-69)$ & 89 & 0.10 & 0.016 & 8.7 & 388 & 150 & 280 \\
\hline & & $-12-5(68-69)$ & 80 & 0.15 & 0.022 & 8.9 & & & \\
\hline & middle & $-13-2(72-73)$ & 89 & 0.15 & 0.016 & 12.6 & 387 & 300 & 160 \\
\hline & Eocene & $-13-5(72-73)$ & 92 & 0.09 & 0.009 & 13.6 & & & \\
\hline & & $-14-2(22-24)$ & 91 & 0.11 & 0.013 & 11.2 & 396 & 27 & 191 \\
\hline & & $-14-5(22-24)$ & 91 & 0.06 & 0.008 & 10.6 & & & \\
\hline & & $-15-2(33-34)$ & 92 & & & & & & \\
\hline & & $-15-5(33-34)$ & 95 & & & & & & \\
\hline & & $-16-2(51-52)$ & 95 & 0.06 & 0.006 & 12.9 & & & \\
\hline & & $-17-2(85-86)$ & 90 & & & & & & \\
\hline & & $-17-5(85-86)$ & 89 & 0.06 & 0.008 & 9.8 & & & \\
\hline & & $-18-2(41-42)$ & 74 & 0.05 & 0.014 & 5.0 & & & \\
\hline & & $-19-2(50-51)$ & 56 & 0.11 & 0.025 & 5.7 & 421 & 73 & 218 \\
\hline & & $-19-5(50-51)$ & 78 & 0.11 & 0.017 & 8.6 & & & \\
\hline & & $-20-2(59-60)$ & 71 & 0.08 & 0.016 & 5.5 & & & \\
\hline & & $-21-2(74-75)$ & 70 & 0.08 & 0.020 & 5.6 & & & \\
\hline & & $-22-2(91-92)$ & 75 & 0.09 & 0.017 & 6.8 & & & \\
\hline 5 & early & $-22-5(91-92)$ & 63 & 0.06 & 0.018 & 4.6 & & & \\
\hline & Eocene & $-23-2(64-65)$ & 17 & 0.15 & 0.046 & 4.3 & & & \\
\hline & to late & $-24-2(19-20)$ & 25 & 0.11 & 0.041 & 3.5 & & & \\
\hline & Paleocene & $-24-5(58-59)$ & 22 & 0.20 & 0.045 & 5.7 & 410 & 0 & 150 \\
\hline & & $-25-2(86-87)$ & 28 & 0.14 & 0.038 & 4.9 & & & \\
\hline & & $-25-5(56-57)$ & 30 & 0.13 & 0.035 & 5.1 & & & \\
\hline & & $-27-2(65-66)$ & 74 & 0.08 & 0.016 & 6.2 & & & \\
\hline & & $-27-5(65-66)$ & 32 & 0.12 & 0.036 & 4.4 & & & \\
\hline & & $-28-2(65-66)$ & 38 & 0.11 & 0.030 & 4.7 & & & \\
\hline & & $-28-5(65-66)$ & 56 & 0.07 & 0.021 & 4.1 & & & \\
\hline 6 & Danian & $-29-2(69-70)$ & 98 & & & & . & & \\
\hline & to late & $-29-5(67-68)$ & 97 & & & & & & \\
\hline & Campanian & $-30-2(102-103)$ & 97 & & & & & & \\
\hline & & $-31-2(62-63)$ & 99 & & & & & & \\
\hline & & $-32-2(69-70)$ & 98 & & & & & & \\
\hline & & $-33-2(10-11)$ & 100 & & & & & & \\
\hline & & $-34-2(31-32)$ & 94 & 0.10 & 0.009 & 15.2 & & & \\
\hline & & $-34-5(31-32)$ & 95 & 0.06 & 0.006 & 15.0 & & & \\
\hline & & $-35-1(3-4)$ & 97 & & & & & & \\
\hline
\end{tabular}

Note: Nitrogen content represents organic + inorganic nitrogen. TOC $=$ total organic carbon, $T_{\max }=\operatorname{maxi}-$ mum pyrolysis temperature. Hydrogen index is in $\mathrm{mg} \mathrm{HC} / \mathrm{g} \mathrm{TOC}$; oxygen index is in $\mathrm{mg} \mathrm{CO} 2 / \mathrm{g} \mathrm{TOC}$. Samples are listed in order of increasing sub-bottom depth. 
Table 2. Organic geochemical data for Site 549.

\begin{tabular}{|c|c|c|c|c|c|c|c|c|c|}
\hline & & & & & & & & ack-Eva & \\
\hline $\begin{array}{l}\text { Lithologic } \\
\text { unit }\end{array}$ & Age & $\begin{array}{c}\text { Sample } \\
\text { (interval in } \mathrm{cm} \text { ) }\end{array}$ & $\underset{(\%)}{\mathrm{CaCO}_{3}}$ & $\begin{array}{l}\text { TOC } \\
\left(\%_{0}\right)\end{array}$ & $\underset{(\%)}{N}$ & $\begin{array}{c}\text { Atomic } \\
\mathrm{C} / \mathrm{N}\end{array}$ & $\begin{array}{c}T_{\max } \\
\left({ }^{\circ} \mathrm{C}\right)\end{array}$ & $\begin{array}{l}\mathrm{H}- \\
\text { index }\end{array}$ & $\begin{array}{l}0 . \\
\text { index }\end{array}$ \\
\hline 1 & Quaternary & $549 \mathrm{~A}-1-1(11-12)$ & 65 & 0.17 & 0.036 & 6.2 & 367 & 29 & 1265 \\
\hline & & $-1-2,30-31$ & 26 & 0.26 & 0.048 & 7.1 & 400 & 19 & 189 \\
\hline & & $-1-4(35-36)$ & 70 & 0.11 & 0.024 & 6.0 & 375 & 27 & 2582 \\
\hline & & $-2-2(15-16)$ & 66 & 0.13 & 0.026 & 6.7 & 371 & 23 & 1951 \\
\hline & & $-2-4(15-16)$ & 16 & 0.30 & 0.045 & 8.9 & 420 & 27 & 737 \\
\hline & & $-3-2(43-44)$ & 5 & 0.66 & 0.066 & 13.4 & 428 & 36 & 217 \\
\hline 2 & late & $-4-1(15-16)$ & 47 & 0.33 & 0.048 & 9.0 & 383 & 70 & 673 \\
\hline & Miocene & $-4-5(15-16)$ & 86 & 0.07 & 0.014 & 7.2 & & & \\
\hline & to & $-5-2(15-16)$ & 86 & 0.06 & 0.012 & 6.8 & & & \\
\hline & middle & $-5-4(15-16)$ & 85 & 0.07 & 0.014 & 6.7 & & & \\
\hline & Eocene & $-6-1(125-126)$ & 93 & 0.05 & 0.006 & 10.2 & & & \\
\hline & & $-7-4(9-10)$ & 91 & & & & & & \\
\hline & & $-8-2(21-22)$ & 93 & 0.04 & 0.006 & 9.3 & & & \\
\hline & & $-8-6(10-11)$ & 90 & 0.04 & 0.007 & 8.2 & & & \\
\hline & & $-9-2(10-11)$ & 93 & 0.04 & 0.006 & 9.2 & & & \\
\hline & & $-9-4(10-11)$ & 93 & 0.03 & 0.006 & 7.5 & n.d. & 67 & 5067 \\
\hline & & $-11-2(16-17)$ & 88 & 0.04 & 0.007 & 7.5 & & & \\
\hline & & $-11-4(16-17)$ & 87 & 0.04 & 0.007 & 7.1 & & & \\
\hline & & $-12-2(55-56)$ & 93 & 0.03 & 0.005 & 8.1 & & & \\
\hline & & $-13-2(5-6)$ & 88 & 0.06 & 0.009 & 9.5 & & & \\
\hline & & $-14-2(25-26)$ & 89 & 0.08 & 0.010 & 10.2 & 368 & 251 & 988 \\
\hline & & $-15-2(5-6)$ & 85 & & & & & & \\
\hline & & $-17-2(5-6)$ & 97 & & & & & & \\
\hline & & $-18-1(5-6)$ & 90 & 0.05 & 0.007 & 8.7 & & & \\
\hline & & $-22, \mathrm{CC}(27-28)$ & 93 & 0.02 & 0.005 & 6.4 & & & \\
\hline & & $-24-2(5-6)$ & 95 & 0.01 & 0.003 & 5.3 & & & \\
\hline & & $-25-2(5-6)$ & 86 & & & & & & \\
\hline & & $-26-1(37-38)$ & 89 & 0.02 & 0.005 & 5.4 & & & \\
\hline & & $-27-1(37-38)$ & 89 & & & & & & \\
\hline & & $-28-1(56-57)$ & 90 & 0.03 & 0.007 & 6.5 & & & \\
\hline & & $-33-1(29-30)$ & 84 & 0.04 & 0.008 & 6.0 & & & \\
\hline & & $-34-1(30-31)$ & 89 & & & & & & \\
\hline & & $-35-1(30-31)$ & 86 & & & & & & \\
\hline & & $-36-1(10-11)$ & 95 & & & & & & \\
\hline & & $-37-1(10-11)$ & 89 & & & & & & \\
\hline & & $-38-1(11-12)$ & 84 & & & & & & \\
\hline & & $-39-1(11-12)$ & 86 & 0.05 & 0.010 & 6.9 & & & \\
\hline & & $-41-1(7-8)$ & 85 & 0.05 & 0.010 & 6.7 & & & \\
\hline & & $-42-1(3-4)$ & 75 & 0.05 & 0.015 & 4.8 & & & \\
\hline & & $549-2-2(44-46)$ & 82 & 0.04 & 0.009 & 5.2 & n.d. & 0 & 0 \\
\hline & & $-4-2(58-59)$ & 83 & 0.05 & 0.010 & 6.1 & & & \\
\hline & & $-5-2(57-58)$ & 75 & & & & & & \\
\hline & & $-6-5(63-64)$ & 70 & & & & n.d. & 0 & 0 \\
\hline & & $-7.2(29-30)$ & 62 & 0.08 & 0.020 & 4.9 & & & \\
\hline & & $-8-2(72-73)$ & 69 & 0.05 & 0.016 & 4.1 & & & \\
\hline & & $-9-2(56-57)$ & 74 & & & & & & \\
\hline & & $-10-2(45-46)$ & 76 & & & & & & \\
\hline 3 & early & $-10-5(51-52)$ & 72 & 0.06 & 0.013 & 6.1 & n.d. & 0 & 0 \\
\hline & Eocene & $-11-2(59-60)$ & 15 & 0.15 & 0.026 & 7.5 & n.d. & 0 & 0 \\
\hline & to late & $-11-5(109-110)$ & 33 & 0.10 & 0.032 & 4.2 & & & \\
\hline & Paleocene & $-12-1(48-49)$ & 46 & & & & & & \\
\hline & & $-13-2(43-44)$ & 62 & & & & & & \\
\hline & & $-14-2(55-56)$ & 63 & 0.07 & 0.016 & 5.8 & & & \\
\hline & & $-14-4(16-17)$ & 68 & & & & & & \\
\hline & & $-15-2(56-57)$ & 39 & 0.10 & 0.030 & 4.1 & & & \\
\hline & & $-16-2(56-57)$ & 41 & & & & n.d. & 0 & 0 \\
\hline & & $-17-2(79-80)$ & 53 & 0.05 & 0.025 & 2.4 & & & \\
\hline & & $-18-2(35-36)$ & 43 & & & & & & \\
\hline & & $-19-2(41-42)$ & 63 & 0.05 & 0.009 & 6.3 & & & \\
\hline & & $-20-5(9-10)$ & 57 & 0.10 & 0.021 & 6.3 & & & \\
\hline 4 & early & $-21-2(19-20)$ & 73 & 0.09 & 0.015 & 7.9 & 415 & 2 & 500 \\
\hline & Paleocene & $-22-1(43-44)$ & 94 & 0.16 & 0.017 & 13.0 & & & \\
\hline & to early & $-22-2(105-106)$ & 95 & 0.04 & 0.004 & 12.6 & & & \\
\hline & Turonian & $-23-2(54-55)$ & 94 & 0.03 & 0.002 & 17.4 & & & \\
\hline & & $-24-2(18-19)$ & 92 & 0.04 & 0.005 & 11.6 & & & \\
\hline & & $-25-1(37-38)$ & 90 & 0.10 & 0.011 & 13.1 & n.d. & 0 & 0 \\
\hline & & $-25-2(24-25)$ & 86 & 0.07 & 0.006 & 15.3 & & & \\
\hline 5 & early & $-26-1(24-25)$ & 84 & 0.05 & 0.007 & 9.5 & n.d. & 0 & 0 \\
\hline & Turonian & $-27-1(10-11)$ & 67 & 0.06 & 0.012 & 7.4 & n.d. & 0 & 0 \\
\hline & to early & $-27-1(29-30)$ & 31 & 3.37 & 0.166 & 25.3 & 428 & 316 & 46 \\
\hline & Cenomanian & $-27-1(42-43)$ & 3 & 0.28 & 0.021 & 17.3 & 415 & 54 & 100 \\
\hline & & $-27-1(50-51)$ & 9 & 3.51 & 0.162 & 27.1 & 418 & 318 & 29 \\
\hline & & $-28-1(73-74)$ & 69 & 0.08 & 0.010 & 10.4 & n.d. & 0 & 0 \\
\hline & & $-28-2(25-26)$ & 75 & 0.07 & 0.008 & 12.0 & & & \\
\hline & & $-29-1(19-20)$ & 67 & 0.05 & 0.006 & 1.2 & & & \\
\hline 6 & middle & $-32-1(17-18)$ & 22 & 0.36 & 0.027 & 16.2 & 420 & 31 & 136 \\
\hline & to early & $-33, \mathrm{CC}$ & 17 & & & & 427 & n.d. & n.d. \\
\hline & Albian & $-34-1(52-53)$ & 51 & 0.25 & 0.017 & 19.1 & 412 & 16 & 144 \\
\hline & & $-35-1(7-8)$ & 15 & 0.29 & 0.013 & 29.3 & 425 & 38 & 138 \\
\hline & & $-36-1(20-21)$ & 49 & 0.46 & 0.023 & 24.9 & 421 & 39 & 78 \\
\hline & & $-37-1(31-32)$ & 23 & 0.72 & 0.042 & 22.0 & 417 & 13 & 61 \\
\hline & & $-37-2(32-33)$ & 23 & 0.49 & 0.033 & 18.5 & & & \\
\hline & & $-38-1(34-35)$ & 83 & 0.18 & 0.010 & 21.4 & & & \\
\hline & & $-39-1(6-7)$ & 32 & 0.43 & 0.032 & 17.5 & & & \\
\hline & & $-40-1(7-8)$ & 33 & 0.54 & 0.032 & 21.3 & 417 & 15 & 78 \\
\hline & & $-42-1(38-39)$ & 72 & 0.52 & 0.016 & 40.4 & 426 & 7 & 50 \\
\hline
\end{tabular}


Table 2. (Continued).

\begin{tabular}{|c|c|c|c|c|c|c|c|c|c|}
\hline \multirow[b]{2}{*}{$\begin{array}{c}\text { Lithologic } \\
\text { unit }\end{array}$} & \multirow[b]{2}{*}{ Age } & \multirow[b]{2}{*}{$\begin{array}{c}\text { Sample } \\
\text { (interval in } \mathrm{cm} \text { ) }\end{array}$} & \multirow[b]{2}{*}{$\underset{(\%)}{\mathrm{CaCO}_{3}}$} & \multirow[b]{2}{*}{$\begin{array}{l}\text { TOC } \\
(\%)\end{array}$} & \multirow[b]{2}{*}{$\underset{(\%)}{N}$} & \multirow[b]{2}{*}{$\begin{array}{l}\text { Atomic } \\
\mathrm{C} / \mathrm{N}\end{array}$} & \multicolumn{3}{|c|}{ Rock-Eval } \\
\hline & & & & & & & $\begin{array}{l}T_{\max } \\
\left({ }^{\circ} \mathrm{C}\right)\end{array}$ & $\begin{array}{c}\begin{array}{c}H- \\
\text { index }\end{array} \\
\text { in }\end{array}$ & $\begin{array}{c}0 . \\
\text { index }\end{array}$ \\
\hline \multirow[t]{8}{*}{6 (Cont.) } & middle & $-42-2(36-37)$ & 41 & 0.57 & 0,027 & 26.1 & & & \\
\hline & to early & $-43-2(88-89)$ & 28 & 0.72 & 0.029 & 31.3 & 421 & 7 & 63 \\
\hline & Albian & $-44-2(110-111)$ & 58 & 0.34 & 0.024 & 17.9 & & & \\
\hline & & $-45-3(40-41)$ & 40 & 0.28 & 0.018 & 18.9 & & & \\
\hline & & $-46-4(91-92)$ & 32 & 0.33 & 0.023 & 19.1 & 421 & 3 & 115 \\
\hline & & $-47-1(46-47)$ & 32 & 0.33 & 0.027 & 16.6 & & & \\
\hline & & $-47-4(72-73)$ & 40 & 0.26 & 0.018 & 19.3 & & & \\
\hline & & $-48-1(33-34)$ & 49 & 0.17 & 0.014 & 16.9 & & & \\
\hline \multirow[t]{8}{*}{8} & early & $-54-2(91-92)$ & 31 & 0.26 & 0.030 & 11.9 & 417 & 12 & 103 \\
\hline & late & $-55-2(114-115)$ & 52 & 0.21 & 0.022 & 12.7 & & & \\
\hline & Barremian & $-56-1(44-45)$ & 80 & 0.09 & 0.010 & 13.1 & 417 & 11 & 289 \\
\hline & to early & $-57-2(53-55)$ & 16 & 0.42 & 0.036 & 14.3 & 422 & 17 & 83 \\
\hline & Barremian & $-58-2(38-39)$ & 24 & 0.40 & 0.030 & 17.8 & 425 & 20 & 88 \\
\hline & & $-59-3(52-53)$ & 21 & 0.47 & 0.036 & 17.6 & & & \\
\hline & & $-60-5(127-128)$ & 52 & 0.27 & 0.015 & 24.0 & 418 & 15 & 107 \\
\hline & & $-61-2(107-108)$ & 24 & 0.36 & 0.025 & 19.2 & 412 & 29 & 108 \\
\hline 9 & early & $-70-1(30-31)$ & 1 & 0.30 & 0.038 & 10.4 & 427 & 13 & 80 \\
\hline & Barremian & $-70-1(75-76)$ & $i$ & 0.37 & 0.036 & 13.3 & 418 & 27 & 57 \\
\hline 10 & early & $-72-1(94-95)$ & 16 & 0.67 & 0.043 & 20.6 & 414 & 58 & 55 \\
\hline & Barremian & $-73-1(51-52)$ & 25 & 0.47 & 0.028 & 22.1 & 409 & 0 & 70 \\
\hline & & $-74-2(24-25)$ & 8 & 0.47 & 0.029 & 21.4 & & & \\
\hline & & $-75-2(81-82)$ & 33 & 0.35 & 0.025 & 18.1 & 412 & 23 & 206 \\
\hline & & $.75, \mathrm{CC}(14-15)$ & 4 & 0.16 & 0.028 & 7.6 & & & \\
\hline & & $-76-2(51-52)$ & 9 & 0.80 & 0.034 & 30.6 & & & \\
\hline & & $-78-1(30-31)$ & 34 & 0.07 & 0.025 & 3.6 & 415 & 14 & 571 \\
\hline & & $-79-1(7-8)$ & 0 & 4.20 & 0.101 & 54.6 & 415 & 15 & 40 \\
\hline & & $-79-1(79-80)$ & 4 & 0.27 & 0.024 & 15.0 & 412 & 15 & 167 \\
\hline & & $-80-1(80-81)$ & 6 & & & & 421 & n.d. & n.d. \\
\hline & & $-80-2(26-27)$ & 31 & 0.11 & 0.012 & 6.9 & 426 & 18 & 546 \\
\hline & & $-81-1(56-57)$ & 0 & 0.10 & 0.034 & 4.1 & & & \\
\hline & & $-81-2(47-48)$ & 0 & 0.36 & 0.036 & 13.5 & 431 & 25 & 119 \\
\hline & & $-82-1(28-29)$ & 19 & 0.26 & 0.020 & 16.7 & 414 & 27 & 307 \\
\hline & & $-82-1(126-127)$ & 2 & 0.08 & 0.033 & 3.2 & 414 & 25 & 400 \\
\hline & & $.82 .2(11-12)$ & 0 & 0.19 & 0.041 & 6.2 & & & \\
\hline & & $-82-2(71-72)$ & i & 0.91 & 0.043 & 28.3 & 415 & 40 & 122 \\
\hline & & $-83-2(57-58)$ & 0 & 0.13 & 0.026 & 6.6 & & & \\
\hline & & $-83-2(73-74)$ & 0 & 0.10 & 0.016 & 8.5 & 420 & 54 & 100 \\
\hline & & $-84-1(3-4)$ & 0 & 0.19 & 0.024 & 10.3 & & & \\
\hline & & $.84-1(130-131)$ & 2 & 1.52 & 0.040 & 50.2 & 425 & 49 & 74 \\
\hline & & $-84-2(29-30)$ & 0 & 0.31 & 0.032 & 12.8 & 423 & 84 & 68 \\
\hline & & $-84-2(97-98)$ & 0 & 0.12 & 0.023 & 6.9 & & & \\
\hline & & $-85-1(69-70)$ & 26 & 0.38 & 0.032 & 15.7 & & & \\
\hline & & $.85-1(100-101)$ & 1 & 1.62 & 0.045 & 48.1 & 422 & 134 & 50 \\
\hline & & $-85-2(38-39)$ & 4 & 3.01 & 0.065 & 60.5 & 418 & 95 & 64 \\
\hline & & $-85-2(40-4$ & 14 & 2.43 & 0.057 & 55.8 & 412 & 102 & 53 \\
\hline & & $-86-1(120-12$ & 0 & 0.22 & 0.042 & 7.0 & & & \\
\hline & & $-86-2(118-11)$ & 4 & 0.81 & 0.040 & 26.9 & 416 & 40 & 90 \\
\hline & & $-87-1(137-138)$ & 2 & 2.75 & 0.059 & 60.6 & & & \\
\hline & & $-87-2(82-83)$ & 43 & 0.41 & 0.027 & 20.5 & 421 & 34 & 127 \\
\hline & & $-87-3(19-2$ & 35 & 0.41 & 0.0 & 17.4 & & & \\
\hline & & $-88-1(44-4$ & 62 & 0.26 & 0.020 & 17.0 & 414 & 42 & 242 \\
\hline & & $-88-2(63-64)$ & 2 & 0.07 & 0.030 & 3.0 & & & \\
\hline & & $-88-3(28-29)$ & 0 & 0.15 & 0.044 & 4.6 & 417 & 7 & 73 \\
\hline & & $-88-3(121-122)$ & 0 & 0.60 & 0.051 & 15.6 & & & \\
\hline & & $-89.1(95-96)$ & 63 & & & & & & \\
\hline & & $-89-2(38-39)$ & 62 & 0.25 & 0.020 & 14.6 & & & \\
\hline & & $-89, \mathrm{CC}$ & 29 & 0.13 & 0.024 & 6.9 & & & \\
\hline & & -90-1 (113-1144) & 0 & 0.75 & 0.0 & 32.7 & & & \\
\hline & & $-90-3(19-2$ & 1 & 0.5 & 0.0 & 19.5 & & & \\
\hline & & $-91-1<6$ & i & & & 63.0 & 416 & 134 & 225 \\
\hline & & $-91.2(20)$ & 0 & 5.82 & & 89.3 & 415 & 91 & 88 \\
\hline & & $-91-2(70)$ & i & 0.72 & 0.023 & 40.7 & & & \\
\hline & & $-92-1(85)$ & 0 & 4.28 & 0.092 & 61.1 & 416 & 152 & 129 \\
\hline & & $-92-1(104-105)$ & 0 & 3.93 & 0.069 & 74.9 & 407 & 137 & 65 \\
\hline & & $-93-1(83-84)$ & 2 & 1.33 & 0.049 & 35.7 & 415 & 19 & 41 \\
\hline & & $-93, \mathrm{CC}(16-17)$ & 1 & 0.63 & 0.023 & 36.2 & 408 & 35 & 44 \\
\hline 11 & $\begin{array}{c}\text { lower } \\
\text { Paleozoic }\end{array}$ & $-94-1(141)$ & 4 & 0.05 & 0.017 & 3.6 & & & \\
\hline
\end{tabular}

Note: Column headings and order of samples as in Table I. n.d. $=$ not determinable.

organic carbon content. These sediments are similar in age and lithology to those of Unit 4 at Site 548.

\section{Unit 3}

Unit 3 appears in Hole 549 from Core 10, Section 2, $65 \mathrm{~cm}$ through Core 20. The sediments are less calcareous than those in Unit 2 and have slightly higher TOC values. The Rock-Eval analyses are not reliable but indi- cate no hydrocarbon source potential. These sediments are similar in age and lithology to those of Unit 5 at Site 548.

\section{Unit 4}

Unit 4 appears in Hole 549 from Core 21 to Core 26, Section $1,10 \mathrm{~cm}$. It consists of nannofossil chalks that are nearly pure carbonates, with very little organic car- 


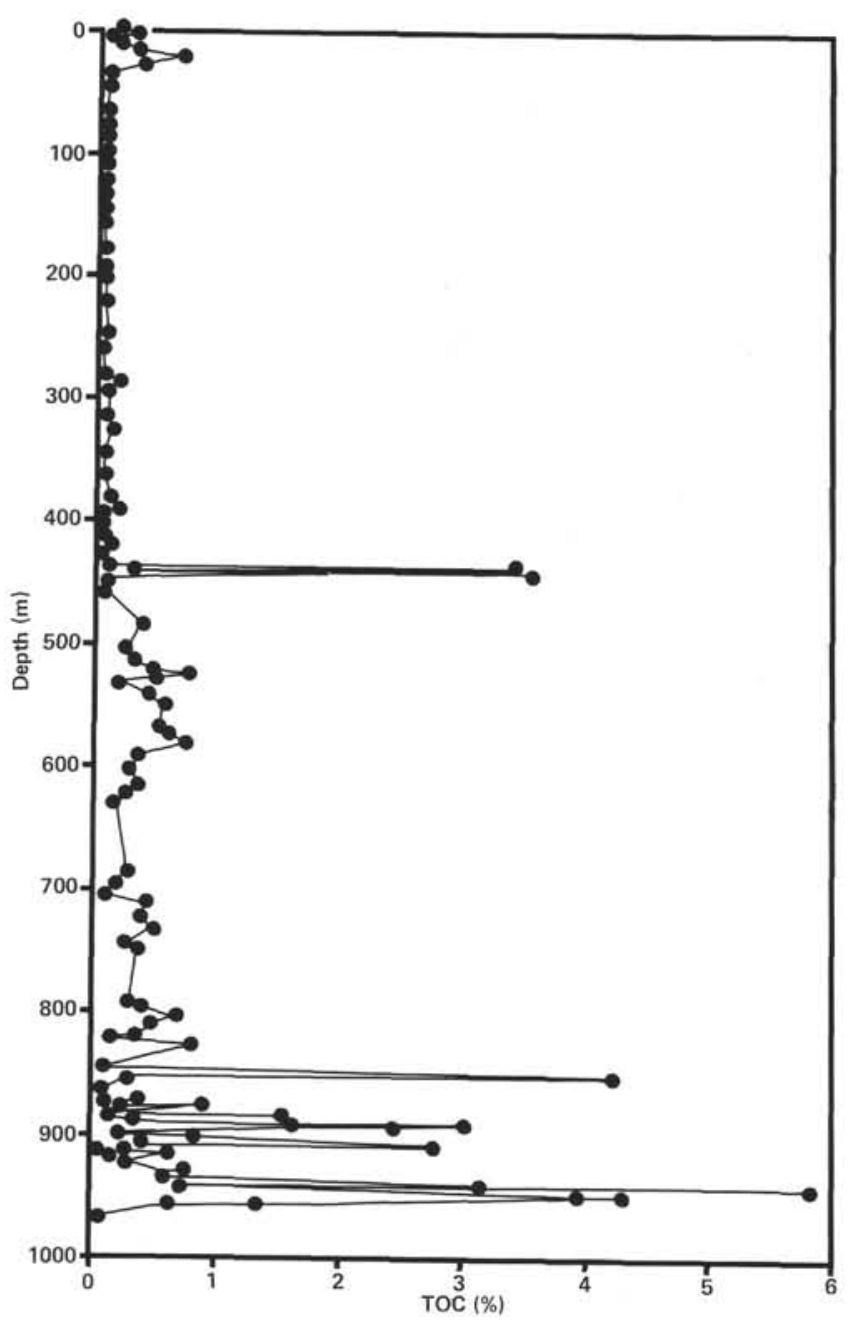

Figure 3. TOC versus depth for Site 549.

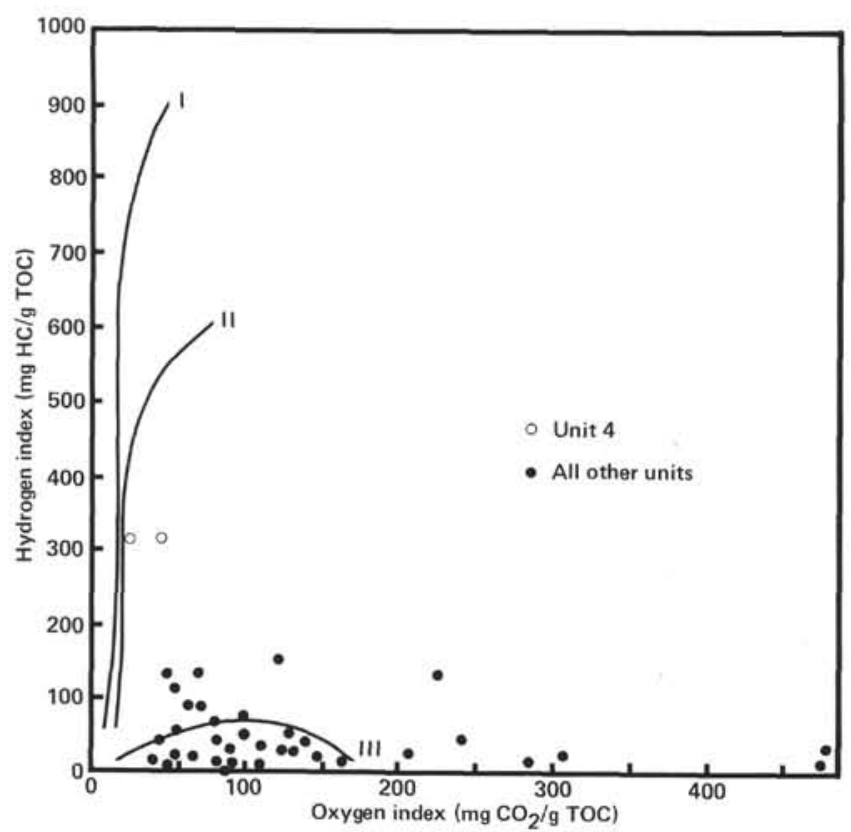

Figure 4. Hydrogen and oxygen indices for Site 549 kerogens. bon. The Rock-Eval analyses are not reliable. These sediments are similar in age and lithology to those of Unit 6 at Site 548 .

\section{Unit 5}

Unit 5 appears in Hole 549 from Core 26, Section 1, $10 \mathrm{~cm}$ through Core 31 . It comprises organic-carbonlean chalks, organic-carbon-rich laminated black shales, and an ash bed. Core 27 , which unfortunately consists of only $60 \mathrm{~cm}$ of material, contains two distinct laminated, siliceous (opal CT), slightly to moderately calcareous ( 9 and $31 \% \mathrm{CaCO}_{3}$ in two samples) black shales of late Cenomanian age. The organic carbon contents of these sediments are relatively high $(3.5 \%)$, although not as high as the intense black color (N1) would suggest. The black coloration probably stems largely from finely disseminated pyrite or the chert matrix or both. The two black zones were separated by an ash bed at least several centimeters thick. Because of the poor recovery it was impossible to determine the total thickness or number of black zones or ash beds actually present in the subsurface.

The Rock-Eval pyrolysis results are much different for the two black shale samples $(549-27-1,29-30 \mathrm{~cm}$ and $549-27-1,50-51 \mathrm{~cm}$ ) than for the other samples from Site 549 (Table 2$)$. The hydrogen indices $(\approx 317 \mathrm{mg} \mathrm{HC} /$ $\mathrm{g}$ TOC) and nitrogen contents (atomic $\mathrm{C} / \mathrm{N}_{\text {org }} \approx 20$ : Waples, "Nitrogen," this volume) indicate that the kerogens are of mixed marine and terrestrial origin (Types II and III).

\section{Units 6 and 8}

Unit 6 appears in Hole 549 from Core 32 to Core 52, Section $1,15 \mathrm{~cm}$, and Unit 8 appears in Hole 549 from Core 53, Section 1, $30 \mathrm{~cm}$ through Core 61 . The units consist of moderately calcareous sediments with slightly elevated organic carbon contents (maximum measured TOC $=0.72 \%$ ). The Rock-Eval analyses indicate that the organic matter is highly oxidized and of terrestrial origin.

\section{Units 7 and 9}

Unit 7 appears in Hole 549 from Core 52, Section 1, $15 \mathrm{~cm}$ to Core 53 , Section $1,30 \mathrm{~cm}$, and Unit 9 appears in Hole 549 from Cores 62 to 71 . No samples from Unit 7 were analyzed. The two samples from Unit 9 are noncalcareous and contain modest amounts of oxidized organic matter of terrestrial provenance.

\section{Unit 10}

Unit 10 appears in Hole 549 from Cores 72 to 93 . It consists of chiefly noncalcareous sediments. Some samples contain common large fragments of wood and other terrestrial plant debris that strongly affect the TOC values (up to $5.8 \%$ ). More typical values lie in the range from 0.5 to $1.0 \%$. Where macroscopic plant fragments are absent, the clay matrix itself contains relatively little organic carbon, and TOC values are low. Rock-Eval pyrolysis and nitrogen contents (atomic $\mathrm{C} / \mathrm{N}_{\text {org }} \approx 80$ : Waples, "Nitrogen," this volume) corroborate the interpretation of the organic matter as mainly woody in origin. 


\section{Site $\mathbf{5 5 0}$}

The Tertiary and Quaternary sediments at Site 550 have lower TOC values than coeval sediments at Sites 548 and 549 , in part as a consequence of the greatly condensed Quaternary section at Site 550. The Tertiary sediments are highly calcareous.

The Upper Cretaceous sediments include several meters of noncalcareous clay that was deposited below the CCD; these clays are slightly enriched in organic matter. The Cenomanian sediments include black laminated organic-carbon-rich calcareous shales interbedded with gray to white, homogeneous, calcareous mudstones.

The organic geochemistry of the Site 551 sediments is reported in Table 3. The TOC values are plotted as a function of depth in Figure 5. The lithologic units are discussed separately below.

\section{Quaternary}

Three samples were analyzed from the single core taken from Holocene/Pleistocene sediments. The organic carbon, carbonate content, and Rock-Eval pyrolysis results are similar to those from Unit 1 at Sites 548 and 549.

\section{Units 1 and 2}

Units 1 and 2 appear in Hole 550 from Core 2 to Core 36, Section 3, $95 \mathrm{~cm}$. Carbonate contents are high in these nannofossil oozes, chalks, and marly chalks. Organic carbon contents are low, with the higher values occurring in the less calcareous samples. Rock-Eval analyses indicate that the organic matter is highly oxidized and refractory, as well as thermally immature. These units are very similar to Units 2 to 4 at Site 549 and Units 4 to 6 at Site 548.

\section{Unit 3}

Unit 3 appears in Hole 550 from Core 35, Section 3, $95 \mathrm{~cm}$ through Core 40 and in Hole 550B from Core 2 to Core 13, Section $3,50 \mathrm{~cm}$. The chalks in Unit 3 are similar in TOC, carbonate content, and Rock-Eval pyrolysis characteristics to those of Units 1 and 2 . The turbidite sequences within Unit 3 are somewhat more calcareous than the more hemipelagic sediments (e.g., $82-90 \% \mathrm{CaCO}_{3}$ in the turbidite in Core $11 ; 41-48 \% \mathrm{CaCO}_{3}$ in the hemipelagic sediments of Cores 9 and 10). Because the preservation of calcareous microfossils was poor in the hemipelagic sequences, it is likely that at least part of the carbonate depletion relative to the turbidites is a result of dissolution.

\section{Unit 4}

Unit 4 appears in Hole 550B from Core 13, Section 3, $50 \mathrm{~cm}$ to Core 15, Section 4, $87 \mathrm{~cm}$. Except for a few turbiditic chalks present at irregular intervals in Subunit $4 \mathrm{~b}$, the sediments in Unit 4 are only faintly calcareous, having been deposited below the CCD. They are quite similar to the "multicolored claystones" described by Arthur (1979a) from Leg 43. The TOC values are all low to moderate (maximum $0.67 \%$ ), and in this unit they are closely related to sediment color (Fig. 6).

The hydrogen indices for the multicolored claystones are uniformly low for all sediment colors $(\approx 30 \mathrm{mg} \mathrm{HC}$ ) g TOC). The oxygen indices, however, show a definite tendency to increase with decreasing TOC (Fig. 7).

\section{Unit 5}

Unit 5 appears in Hole 550B from Core 15, Section 4, $87 \mathrm{~cm}$ to Core 25 , Section $4,87 \mathrm{~cm}$. In this unit lightcolored (whitish, light gray, reddish, and brownish), bioturbated, organic-carbon-lean (TOC $<0.2 \%$ ) sediments are interbedded with gray to dark gray, bioturbated sediments (TOC $=0.2-0.8 \%$ ), blackish, weakly laminated to faintly bioturbated sediments (TOC $=0.8-1.5 \%$ ), and black, finely laminated, unbioturbated sediments (TOC $=1.5-2.4 \%$ ). Color changes are often gradational, progressing from irregularly light to dark and back to light again.

In contrast to the black claystones in Unit 4, the black laminated shales in Unit 5 have relatively high hydrogen indices, averaging $270 \mathrm{mg} \mathrm{HC} / \mathrm{g}$ TOC in Cores 16 to 18 and 200 in Cores 24 and 25 . These values suggest that the organic matter is of mixed marine and terrestrial origin.

Carbonate contents are slightly higher in the organiccarbon-rich intervals than in the lean ones (Fig. 8). These higher carbonate values could be the result of either more rapid carbonate accumulation (implying higher productivity), less dissolution, or enrichment in $\mathrm{CaCO}_{3}$ by late diagenetic processes. A similar relationship was seen in Pleistocene sediments of moderate organic richness from the North Pacific (Heath et al., 1977).

\section{Unit 6}

Unit 6 appears in Hole 550B from Core 25, Section 4, $87 \mathrm{~cm}$ through Core 30 . Two samples of sediment interlayered with basalt were analyzed. The low nitrogen (compared with other samples of comparable TOC) and water contents (observed during $\mathrm{CHN}$ analysis but not reported formally) indicate that the sediments have been somewhat baked. Except for the low carbonate content $(14 \%)$ of the Core 30 sample, the two samples are similar to the organic-carbon-lean, highly oxidized sediments in Unit 5.

\section{Site 551}

\section{Unit 1}

Unit 1 appeared in Hole 551 in Core 1, the only core taken in Holocene-Pleistocene sediments. (The organic geochemistry of the Site 551 sediments is shown in Table 4.) Core 1 lay immediately below the seafloor and was recovered with the hydraulic piston corer. In this core, samples were taken approximately every $10 \mathrm{~cm}$ in order to study the early diagenesis of organic carbon. Figure 9 shows the relationship observed between TOC and carbonate content in the uppermost $5.5 \mathrm{~m}$ of sediment. For sediments of relatively constant lighologic composition $\left(26-45 \% \mathrm{CaCO}_{3}\right)$, there is a slight decrease in TOC with increasing depth of burial (Fig. 10).

\section{Units 2 to 4 and 6}

Units 2 to 4 appear in Hole 551 from Core $\mathrm{H} 1$ to Core 5, Section 2, $60 \mathrm{~cm}$, and Unit 6 appears in Core 6 from Section 1 to Section $3,92 \mathrm{~cm}$. The Eocene to late 
Table 3. Organic geochemical data for Site 550.

\begin{tabular}{|c|c|c|c|c|c|}
\hline & & & & & \\
\hline $\begin{array}{l}\text { Lithologic } \\
\text { unit }\end{array}$ & Age & $\begin{array}{c}\text { Sample } \\
\text { (interval in } \mathrm{cm} \text { ) }\end{array}$ & $\begin{array}{c}\mathrm{CaCO}_{3} \\
(\%)\end{array}$ & $\begin{array}{l}\text { TOC } \\
(\%)\end{array}$ & $\begin{array}{l}N \\
(\%)\end{array}$ \\
\hline- & Quaternary & $550-1-1(20-21)$ & 68 & 0.18 & 0.039 \\
\hline & & $-1.2(20-21)$ & 24 & 0.34 & 0.062 \\
\hline & & $-1-4(21-22)$ & 72 & 0.12 & 0.024 \\
\hline 1 & Pliocene & $-2-1(49-50)$ & 89 & 0.06 & 0.011 \\
\hline & to middle & $-3 \cdot 2(70-71)$ & 81 & 0.06 & 0.015 \\
\hline & Oligocene & $-4-2(80-82)$ & 87 & 0.05 & 0.011 \\
\hline & & $-7-2(12-13)$ & 90 & 0.05 & 0.010 \\
\hline & & $-8 \cdot 2(12-13)$ & 85 & 0.09 & 0.014 \\
\hline & & $-10-2(80)$ & 90 & 0.04 & 0.009 \\
\hline & & $-11-1(50)$ & 94 & 0.03 & 0.006 \\
\hline & & $-12-1(50-51)$ & 81 & 0.07 & 0.016 \\
\hline & & $-13-1(45-46)$ & 85 & 0.05 & 0.012 \\
\hline & & $-14-2(76-77)$ & 81 & 0.06 & 0.014 \\
\hline & & $-15-1(102-103)$ & 77 & 0.11 & 0.018 \\
\hline & & $-16-2(42-43)$ & 95 & & \\
\hline & & $-17-2(31-32)$ & 92 & 0.03 & 0.006 \\
\hline & & $-18-2(48-49)$ & 78 & 0.07 & 0.019 \\
\hline & & $-19-2(53-54)$ & 93 & 0.03 & 0.007 \\
\hline & & $-21-3(111-112)$ & 24 & 0.08 & 0.041 \\
\hline & & $-22-2(18-19)$ & 58 & 0.04 & 0.021 \\
\hline & & $-22-4(18-19)$ & 89 & & \\
\hline & & $-23-1(92-93)$ & 16 & 0.08 & 0.028 \\
\hline & & $-23-2(47-48)$ & 58 & 0.06 & 0.007 \\
\hline & & $-23-3(20-21)$ & 85 & 0.03 & 0.007 \\
\hline 2 & early & $-24-2(124-125)$ & 31 & 0.04 & 0.028 \\
\hline & Oligocene & $-24-5(124-125)$ & 6 & 0.06 & 0.039 \\
\hline & to late & $-25-1(38-39)$ & 49 & 0.03 & 0.020 \\
\hline & Paileocene & $-26-1(56-57)$ & 2 & 0.08 & 0.051 \\
\hline & & $-27-2(45-46)$ & 45 & 0.06 & 0.025 \\
\hline & & $-28-1(46-47)$ & 58 & 0.05 & 0.017 \\
\hline & & $-28-1(68-69)$ & 65 & 0.04 & 0.015 \\
\hline & & $-29-2(46-47)$ & 72 & 0.04 & 0.013 \\
\hline & & $-29-2(68-69)$ & 76 & 0.03 & 0.011 \\
\hline & & $-30-1(61-62)$ & 25 & 0.09 & 0.039 \\
\hline & & $-30-2(44-45)$ & 46 & 0.08 & 0.027 \\
\hline & & $-31-2(10-11)$ & 47 & 0.09 & 0.028 \\
\hline & & $-32-3(66-67)$ & 3 & 0.07 & 0.005 \\
\hline & & $-32-7(42-43)$ & 47 & 0.10 & 0.026 \\
\hline & & $-33-2(117-118)$ & 29 & 0.11 & 0.049 \\
\hline & & $-34-1(2-3)$ & 47 & 0.08 & 0.025 \\
\hline & & $-34-1(3)$ & 47 & 0.08 & 0.025 \\
\hline & & $-35-1(23-24)$ & 57 & 0.05 & 0.006 \\
\hline & & $-35-2(12-13)$ & 10 & 0.08 & 0.023 \\
\hline & & $-35-3(129-130)$ & 6 & 0.10 & 0.020 \\
\hline & & $-35-5(12-13)$ & 3 & 0.11 & 0.024 \\
\hline 3 & late & $-37-2(31-32)$ & 53 & 0.06 & 0.009 \\
\hline & Palcocene & $-37-4(31-32)$ & 69 & 0.10 & 0.013 \\
\hline & to early & $-38-2(31-32)$ & 68 & 0.07 & 0.011 \\
\hline & Maestrichtian & $-38-6(66-67)$ & 63 & 0.05 & 0.011 \\
\hline & or Campanian & $-39-2(30-31)$ & 66 & 0.05 & 0.010 \\
\hline & & $-39-5(92-93)$ & 38 & 0.04 & 0.020 \\
\hline & & $550 \mathrm{~B}-1-2(35-36)$ & 95 & & \\
\hline & & $-1-2(98-99)$ & 46 & 0.08 & 0.025 \\
\hline & & $-1-6(105-106)$ & 33 & 0.05 & 0.022 \\
\hline & & $-2-1(138-139)$ & 87 & 0.07 & 0.008 \\
\hline & & $-2-3(29-30)$ & 30 & 0.04 & 0.026 \\
\hline & & $-2-3(119-120)$ & 54 & 0.03 & 0.017 \\
\hline & & $550-41.2(55-56)$ & 78 & 0.03 & 0.007 \\
\hline & & 550 B-3-2 (66-67) & 87 & 0.04 & 0.007 \\
\hline & & $550-42-2(55-56)$ & 98 & & \\
\hline & & $550 \mathrm{~B}-4-1(15-16)$ & 83 & 0.04 & 0.009 \\
\hline & & $550-43-2(29-30)$ & 93 & & \\
\hline & & $550 \mathrm{~B}-5-2(15-16)$ & 77 & 0.05 & 0.010 \\
\hline & & $-7-1(17-18)$ & 95 & & \\
\hline & & $-7-1(102-103)$ & 56 & 0.13 & 0.020 \\
\hline & & $.7-2(88-89)$ & 91 & 0.05 & 0.006 \\
\hline & & $-8-1(15-16)$ & 92 & & \\
\hline & & $550-47-1(64-65)$ & 54 & 0.04 & 0.019 \\
\hline & & $550 \mathrm{~B}-8-2(91-92)$ & 88 & 0.08 & 0.007 \\
\hline & & $-8-3(0-1)$ & 88 & & \\
\hline & & $-8-3(56-57)$ & 89 & & \\
\hline & & $-8-3(102-103)$ & 87 & & \\
\hline & & $.8-4(23-24)$ & 88 & & \\
\hline & & $.8-4(121-122)$ & 86 & & \\
\hline & & $-8-5(15-16)$ & 86 & & \\
\hline & & $-8-5(50-51)$ & 82 & & \\
\hline & & $.8-5(56-57)$ & 73 & & \\
\hline & & $-8-6(0-1)$ & 43 & 0.10 & 0.029 \\
\hline & & $-9-3(80-81)$ & 48 & 0.11 & 0.027 \\
\hline & & $.9 .4(0-1)$ & 42 & 0.11 & 0.030 \\
\hline & & $-10-1(49-50)$ & 42 & 0.07 & 0.026 \\
\hline & & $-10-4(41-42)$ & 41 & 0.15 & 0.028 \\
\hline & & $-11-1(33-35)$ & 82 & 0.05 & 0.008 \\
\hline & & $-11-2(24-26)$ & 82 & & \\
\hline & & $-11-3(52-54)$ & 90 & & \\
\hline & & $-12-1(85-86)$ & 85 & & \\
\hline & & $-12-3(49-50)$ & 35 & 0.06 & 0.019 \\
\hline & & $-12-4(40-41)$ & 58 & 0.06 & 0.012 \\
\hline & & $-13-1(38-39)$ & 92 & & \\
\hline & & $-13-1(95-96)$ & 74 & & \\
\hline & & $-13-2(68-69)$ & 59 & 0.04 & 0.013 \\
\hline
\end{tabular}


Table 3. (Continued).

\begin{tabular}{|c|c|c|c|}
\hline & & & \\
\hline $\begin{array}{l}\text { Lithologic } \\
\text { unit }\end{array}$ & Age & $\begin{array}{c}\text { Sample } \\
\text { (interval in } \mathrm{cm} \text { ) }\end{array}$ & $\begin{array}{c}\mathrm{CaCO}_{3} \\
(\%)\end{array}$ \\
\hline 4 & Santonian & $-13-1(64-66)$ & 10 \\
\hline & or Coniacian, & $-13-3(72-73)$ & 2 \\
\hline & possibly to & $-13-4(8-9)$ & 2 \\
\hline & Turonian & $-13.4(121-122)$ & 6 \\
\hline & & $-13-5(6-8)$ & 4 \\
\hline & & $-13.5(123-124)$ & 2 \\
\hline & & $-13-5(129-130)$ & 0 \\
\hline & & $-13-5(135-136)$ & 0 \\
\hline & & $-13-5(139-140)$ & 0 \\
\hline & & $-13-5(140-141)$ & 2 \\
\hline & & $-13-5(147-148)$ & 1 \\
\hline & & $-13-6(12-13)$ & 1 \\
\hline & & $-13-6(135-137)$ & 4 \\
\hline & & $-13-7(4-5)$ & 1 \\
\hline & & $-14-1(8-9)$ & 2 \\
\hline & & $-14 \cdot 2(12-13)$ & 0 \\
\hline & & $-14-3(18-19)$ & 1 \\
\hline & & $-14-3(69-71)$ & 2 \\
\hline & & $-14-3(120-121)$ & 1 \\
\hline & & $-14.4(22-23)$ & 3 \\
\hline & & $-14-4(66-67)$ & 0 \\
\hline & & $-14-4(86-87)$ & 69 \\
\hline & & $-14-4(92-93)$ & 7 \\
\hline & & $-14-4(118-119)$ & 3 \\
\hline & & $-14.4(127-128)$ & 79 \\
\hline & & $-14.4(149-150)$ & 4 \\
\hline & & $-14-5(33-34)$ & 2 \\
\hline & & $-14-5(52-53)$ & 81 \\
\hline & & $-15.1(94-95)$ & 85 \\
\hline & & $-15-2(20-21)$ & 2 \\
\hline & & $-15-2(136-137)$ & 0 \\
\hline & & $-15 \cdot 3(68-69)$ & 3 \\
\hline & & $-15-3(116-117)$ & 2 \\
\hline & & $-15-4(54-55)$ & 2 \\
\hline 5 & middle & $-15-4(137-139)$ & 81 \\
\hline & Cenomanian & $-15-6(42-44)$ & 80 \\
\hline & to late & $-15-6(112-113)$ & 81 \\
\hline & Albian & $-16-1(41-43)$ & 75 \\
\hline & & $-16-1(107-108)$ & 72 \\
\hline & & $-16-2(51-52)$ & 65 \\
\hline & & $-16-2(102-103)$ & 62 \\
\hline & & $-16-2(149-150)$ & 71 \\
\hline & & $-16-3(74-75)$ & 67 \\
\hline & & $-16-3(85-86)$ & 72 \\
\hline & & $-17-1(56-57)$ & 66 \\
\hline & & $-17-1(64-66)$ & 63 \\
\hline & & $-17-1(69-70)$ & 59 \\
\hline & & $-17-1(86-87)$ & 67 \\
\hline & & $-17-2(35-36)$ & 67 \\
\hline & & $-17-2(107-108)$ & 69 \\
\hline & & $-17-3(132-133)$ & 76 \\
\hline & & $-17-4(112-113)$ & 65 \\
\hline & & $-17, \mathrm{CC}$ & 65 \\
\hline & & $-18-1(11-12)$ & 67 \\
\hline & & $-18-1(41-44)$ & 66 \\
\hline & & $-18-1(111-112)$ & 64 \\
\hline & & $-18-1$ (115-116) & 57 \\
\hline & & $-18.2(2-3)$ & 59 \\
\hline & & $-18-2(28-29)$ & 62 \\
\hline & & $-18-3(60-61)$ & 54 \\
\hline & & $-18-4(112-113)$ & 39 \\
\hline & & $-20-1(22-23)$ & 41 \\
\hline & & $-20-2(42-44)$ & 43 \\
\hline & & $-20-3(30-31)$ & 51 \\
\hline & & $-20-3(128-129)$ & 43 \\
\hline & & $-20-5(96-97)$ & 57 \\
\hline & & $-20-5(138-139)$ & 67 \\
\hline & & $-21-2(34-36)$ & 48 \\
\hline & & $-21-3(145-146)$ & 66 \\
\hline & & $-22-2(31-32)$ & 59 \\
\hline & & $-22-2(73-74)$ & 54 \\
\hline & & $-23-3(107-108)$ & 55 \\
\hline & & $-23-4(24-25)$ & 60 \\
\hline & & $-24-2(35-36)$ & 50 \\
\hline & & $-24-2(54-55)$ & 53 \\
\hline & & $-24-3(40-41)$ & 43 \\
\hline & & $-24-3(43-44)$ & 47 \\
\hline & & $-24-3(46-47)$ & 51 \\
\hline & & $-24-3(50-52)$ & 54 \\
\hline & & $-24-3(52-53)$ & 48 \\
\hline & & $-24-3(55-56)$ & 43 \\
\hline & & $-24-3(72-73)$ & 51 \\
\hline & & $-25-1(73-74)$ & 60 \\
\hline & & $-25-1(107-108)$ & 60 \\
\hline & & $-25-1(147-148)$ & 59 \\
\hline & & $-25-2(97-98)$ & 51 \\
\hline & & $-25-2(133-134)$ & 51 \\
\hline & & $-25-3(67-68)$ & 64 \\
\hline & & $-25-3(125-126)$ & 54 \\
\hline & & $.25-4(20-21)$ & 62 \\
\hline & & $.25-4(81-82)$ & 53 \\
\hline 6 & late & $-28-2(0-1)$ & 71 \\
\hline & Albian & $-30-4(7-8)$ & 14 \\
\hline
\end{tabular}

Note: Column headings, order of samples, and abbreviations as in Table 2. 


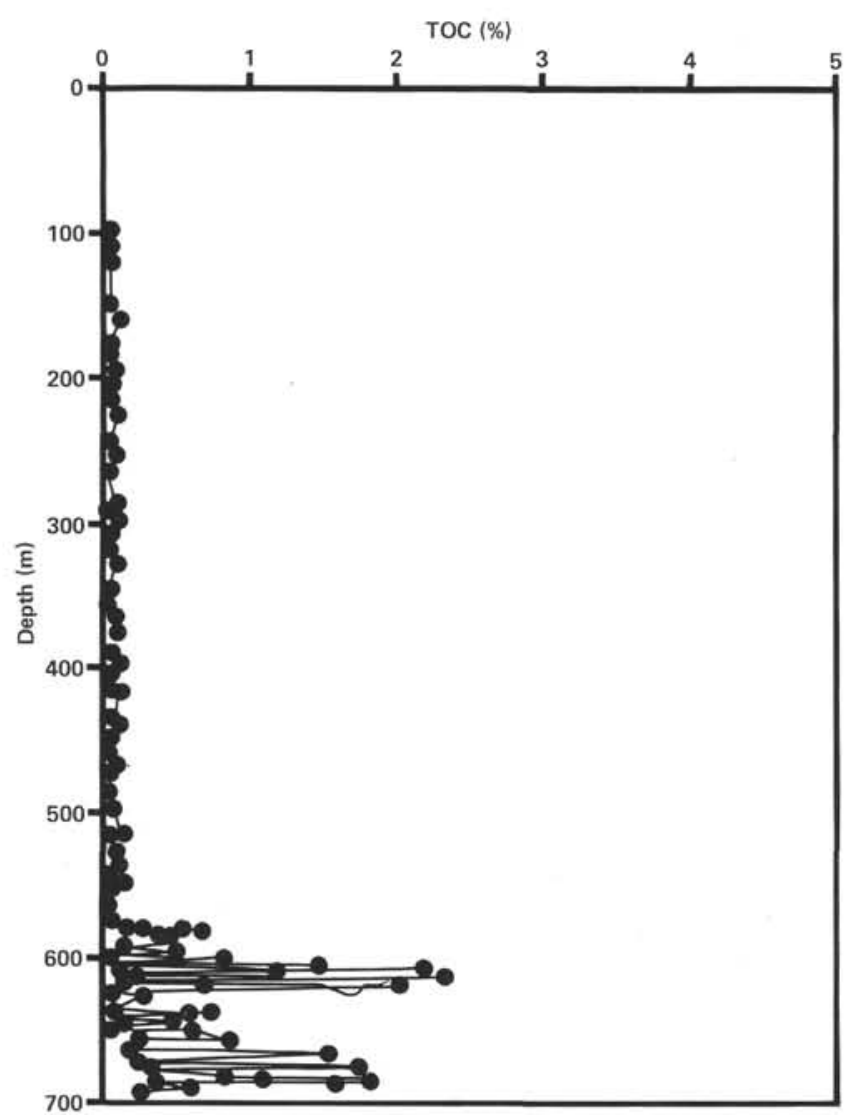

Figure 5. TOC versus depth for Site 550.

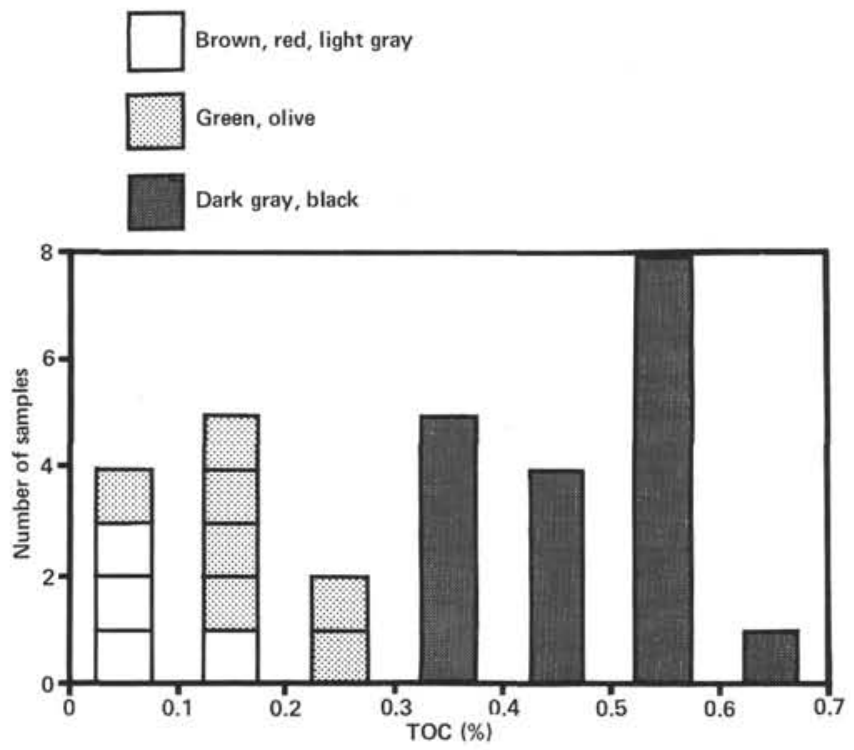

Figure 6. Relationship between sediment color and TOC values for Unit 4 at Site 550 (excluding turbidites).

Cenomanian chalks and oozes comprising lithologic Units 2 to 4 and 6 were perhaps the most organic-carbon-poor sediments encountered on this leg. Although the TOC values ranged from 0.03 to 0.23 , comparable to those in Cenozoic and Cretaceous chalks and oozes at Sites 548, 549 , and 550, no hydrocarbon source potential of these

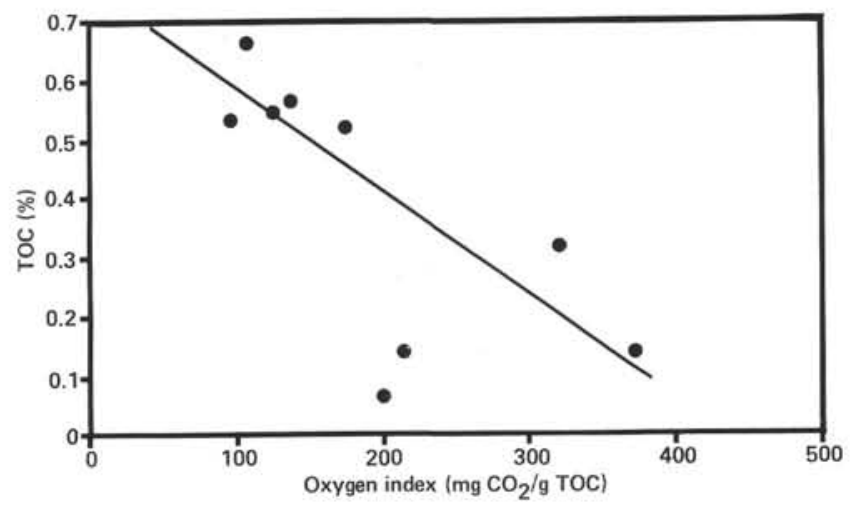

Figure 7. Variation in oxygen index with TOC values for Unit 4 at Site 550 (excluding turbidites).

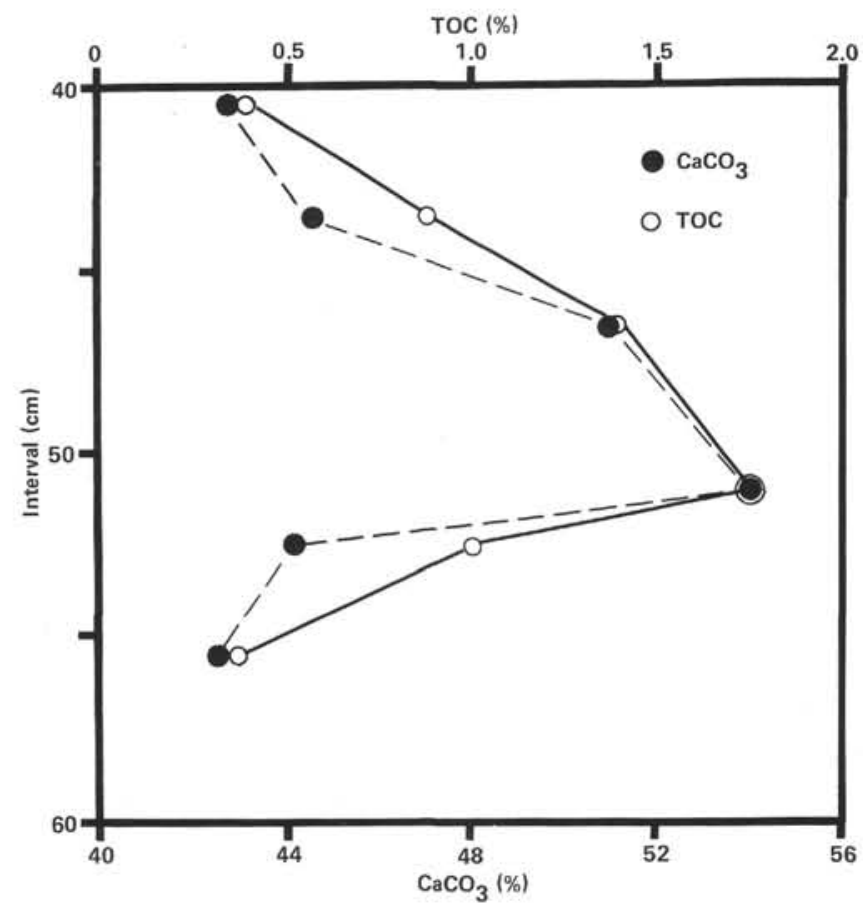

Figure 8. Parallel trends in TOC and $\mathrm{CaCO}_{3}$ content in a black shale rhythm. Hole 550, Core 24, Section 3.

sediments was detectable by Rock-Eval pyrolysis. It is therefore assumed that what little organic matter is contained in these rocks is highly refractory and probably of terrestrial origin.

\section{Unit 5}

Unit 5 appears in Hole 551 from Core 5, Section 2, $60 \mathrm{~cm}$ to the core-catcher sample. A black shale of earliest Turonian age recovered from Unit 5 proved to have the highest organic carbon content $(10.94 \%)$ of any sediment encountered on this leg. This TOC value is the highest yet reported for Cretaceous black shales from the Bay of Biscay margin (maximum values encountered at Sites 400 and 402 , Leg 48 , were approximately $4 \%$; Deroo et al., 1979b). However, a sediment nearly as rich ( $>8 \%$ TOC) was recovered near the Vigo Seamount in a younger (Senonian) bed (Deroo et al., 1979a). The hy- 
Table 4. Organic geochemical data for Site 551.

\begin{tabular}{|c|c|c|c|c|c|c|c|c|}
\hline & & & & & & & & ock-Eva \\
\hline $\begin{array}{l}\text { Lithologic } \\
\text { unit }\end{array}$ & Age & $\begin{array}{c}\text { Sample } \\
\text { (interval in } \mathrm{cm} \text { ) }\end{array}$ & $\underset{(\%)}{\mathrm{CaCO}_{3}}$ & $\begin{array}{l}\text { TOC } \\
(\%)\end{array}$ & $\underset{(\%)}{N}$ & $\underset{\mathrm{C} / \mathrm{N}}{\text { Atomic }}$ & $\begin{array}{l}T_{\max } \\
\left({ }^{\circ} \mathrm{C}\right)\end{array}$ & $\begin{array}{l}\mathrm{H} \text { - } \\
\text { index }\end{array}$ \\
\hline 1 & Quaternary & $551-1-1(15-16)$ & 42 & 0.27 & & & & \\
\hline & & $-1-1(27-28)$ & 35 & 0.33 & & & & \\
\hline & & $-1-1(40-41)$ & 42 & 0.26 & & & & \\
\hline & & $-1-1(50-51)$ & 45 & 0.21 & & & & \\
\hline & & $-1-1(60-61)$ & 26 & 0.23 & & & & \\
\hline & & $-1-1(70-71)$ & 29 & 0.24 & & & & \\
\hline & & $-1-1(77-78)$ & 16 & & & & & \\
\hline & & $-1-1(80-81)$ & 30 & 0.23 & & & & \\
\hline & & $-1-1(90-91)$ & 22 & 0.32 & & & & \\
\hline & & $-1-1(100-101)$ & 25 & 0.33 & & & & \\
\hline & & $-1-1(110-111)$ & 31 & 0.28 & & & & \\
\hline & & $-1-1(120-121)$ & 35 & 0.30 & & & & \\
\hline & & $-1-1(130-131)$ & 38 & 0.26 & & & & \\
\hline & & $-1-1(140-141)$ & 42 & 0.22 & & & & \\
\hline & & $-1-2(30-31)$ & 26 & 0.23 & & & & \\
\hline & & $-1-2(10-11)$ & 52 & 0.20 & & & & \\
\hline & & $-1.2(20-21)$ & 26 & 0.23 & & & & \\
\hline & & $-1-2(30-31)$ & 26 & 0.23 & & & & \\
\hline & & $-1.2(37-38)$ & 28 & 0.24 & & & & \\
\hline & & $-1 \cdot 2(40-41)$ & 33 & 0.20 & & & & \\
\hline & & $-1 \cdot 2(49-50)$ & 40 & 0.19 & & & & \\
\hline & & $-1.2(54-55)$ & 67 & 0.15 & & & & \\
\hline & & $-1-2(62-63)$ & 68 & 0.14 & & & & \\
\hline & & $-1-2(71-72)$ & 80 & 0.16 & & & & \\
\hline & & $-1-2(81-82)$ & 74 & 0.37 & & & & \\
\hline & & $-1-2(90-91)$ & 82 & 0.10 & & & & \\
\hline & & $-1.2(100-101)$ & 78 & 0.09 & & & & \\
\hline & & $-1-2(105-106)$ & 62 & & & & & \\
\hline & & $-1-2(110-111)$ & 66 & 0.12 & & & & \\
\hline & & $-1-2(120-121)$ & 43 & 0.18 & & & & \\
\hline & & $-1-2(130-131)$ & 33 & 0.17 & & & & \\
\hline & & $-1-3(20-21)$ & 32 & 0.25 & & & & \\
\hline & & $-1-3(51-52)$ & 29 & & & & & \\
\hline & & $-1-3(60-61)$ & 31 & 0.21 & & & & \\
\hline & & $-1-3(80-81)$ & 27 & 0.22 & & & & \\
\hline & & $-1-3(100-101)$ & 60 & 0.30 & & & & \\
\hline & & $-1-3(120-121)$ & 20 & 0.40 & & & & \\
\hline & & $-1-3(140-141)$ & 22 & 0.28 & & & & \\
\hline & & $-1-4(20-21)$ & 38 & 0.20 & & & & \\
\hline & & $-1-4(41-42)$ & 26 & 0.23 & & & & \\
\hline & & $-1.4(52-53)$ & 20 & 0.23 & 0.043 & 7.1 & n.d. & 0 \\
\hline & & $-1, C C$ & 35 & 0.19 & & & & \\
\hline 2 & middle & $-\mathrm{H} 1-4(50-51)$ & 63 & 0.11 & 0.021 & 6.7 & n.d. & 0 \\
\hline & Eocene & $-\mathrm{H} 2-1(124-125)$ & 56 & & & & & \\
\hline & to late & $-\mathrm{H} 2-2(124-125)$ & 36 & 0.03 & 0.026 & 1.7 & 408 & 266 \\
\hline & Paleocene & $-\mathrm{H} 2-3(124-125)$ & 36 & & & & & \\
\hline & & $-\mathrm{H} 2-4(114-115)$ & 64 & & & & & \\
\hline & & $-\mathrm{H} 2-4(127-128)$ & 18 & & & & & \\
\hline & & $-\mathrm{H} 2-4(134-135)$ & 37 & & & & & \\
\hline 3 & early & $-\mathrm{H} 2-5(124-125)$ & 86 & & & & & \\
\hline & Maestrichtian & $-2-1(135-136)$ & 89 & & & & & \\
\hline & to late & $-2 \cdot 2(135-136)$ & 89 & 0.02 & 0.004 & 9.1 & n.d. & 0 \\
\hline & Campanian & $-2-3(127-128)$ & 88 & & & & & \\
\hline & & $-3-1(96-97)$ & 87 & & & & & \\
\hline & & $-3-2(96-97)$ & 90 & 0.06 & 0.007 & 11.5 & n.d. & 0 \\
\hline & & $-3-3(96-97)$ & 93 & & & & & \\
\hline & & $-4-1(119-120)$ & 87 & & & & & \\
\hline & & $-4-2(119-120)$ & 87 & 0.04 & 0.006 & 10.2 & n.d. & 0 \\
\hline & & $-4-3(144-145)$ & 88 & & & & & \\
\hline & & $-4-4(116-117)$ & 86 & & & & & \\
\hline & & $-4, C C(15-16)$ & 86 & & & & & \\
\hline 4 & early & $-5-1(3-4)$ & 62 & & & & & \\
\hline & Turonian & $-5-1(7-8)$ & 70 & & & & & \\
\hline & & $-5-1(13-14)$ & 73 & & & & & \\
\hline & & $-5-1(20-21)$ & 75 & & & & & \\
\hline & & $-5-1(28-29)$ & 8 & 0.04 & 0.003 & 15.2 & n.d. & 0 \\
\hline & & $-5-1(33-34)$ & 71 & & & & & \\
\hline & & $-5-1(39-40)$ & 62 & & & & & \\
\hline & & $-5-1(43-44)$ & 53 & & & & & \\
\hline & & $-5-1(46-47)$ & 43 & 0.09 & 0.013 & 10.0 & & \\
\hline & & $-5-1(48-49)$ & 36 & 0.07 & 0.009 & 9.4 & n.d. & 3571 \\
\hline & & $-5-1(49-50)$ & 60 & & & & & \\
\hline & & $-5-1(53-54)$ & 64 & 0.05 & 0.010 & 6.6 & n.d. & 0 \\
\hline & & $-5-1(66-67)$ & 76 & & & & & \\
\hline & & $-5-1(80-81)$ & 72 & & & & & \\
\hline & & $-5-1(93-94)$ & 68 & & & & & \\
\hline & & $-5-1(114-115)$ & 70 & & & & & \\
\hline & & $-5-1(128-129)$ & 73 & & & & & \\
\hline & & $-5-1(138-139)$ & 61 & & & & & \\
\hline & & $-5-1(149-150)$ & 70 & & & & & \\
\hline & & $-5-2(0-1)$ & 57 & & & & & \\
\hline & & $-5-2(3-4)$ & 40 & & & & & \\
\hline & & $-5-2(5-6)$ & 9 & & & & & \\
\hline & & $-5-2(7-8)$ & 18 & & & & & \\
\hline & & $-5-2(8-5)$ & 36 & & & & & \\
\hline & & $-5-2(10-11)$ & 40 & & & & & \\
\hline & & $-5-2(12-13)$ & 54 & & & & & \\
\hline & & $-5-2(15-16)$ & 60 & & & & & \\
\hline
\end{tabular}


Table 4. (Continued).

\begin{tabular}{|c|c|c|c|c|c|c|c|c|c|}
\hline \multirow[b]{2}{*}{$\begin{array}{l}\text { Lithologic } \\
\text { unit }\end{array}$} & \multirow[b]{2}{*}{ Age } & \multirow[b]{2}{*}{$\begin{array}{c}\text { Sample } \\
\text { (interval in } \mathrm{cm} \text { ) }\end{array}$} & \multirow[b]{2}{*}{$\underset{(\%)}{\mathrm{CaCO}_{3}}$} & \multirow[b]{2}{*}{$\begin{array}{l}\text { TOC } \\
(\%)\end{array}$} & \multirow[b]{2}{*}{$\underset{(\%)}{N}$} & \multirow[b]{2}{*}{$\begin{array}{l}\text { Atomic } \\
\mathrm{C} / \mathrm{N}\end{array}$} & \multicolumn{3}{|c|}{ Rock-Eval } \\
\hline & & & & & & & $T_{\max }$ & $\begin{array}{c}\mathrm{H}- \\
\text { index }\end{array}$ & $\begin{array}{l}\text { O. } \\
\text { index }\end{array}$ \\
\hline 4 (Cont.) & $\begin{array}{c}\text { early } \\
\text { Turonian }\end{array}$ & $\begin{array}{l}-5-2(24-25) \\
-5-2(34-35) \\
-5-2(44-45) \\
-5-2(49-51) \\
-5-2(51-52) \\
-5-2(55-56)\end{array}$ & $\begin{array}{r}59 \\
67 \\
63 \\
4 \\
7 \\
34\end{array}$ & 0.03 & 0.007 & 6.1 & n.d. & 0 & 2667 \\
\hline 5 & $\begin{array}{c}\text { early } \\
\text { Turonian }\end{array}$ & $\begin{array}{l}-5-2(68-70) \\
-5-2(80-81) \\
-5-2(91-92) \\
-5, C C\end{array}$ & $\begin{array}{r}0 \\
59 \\
44 \\
0\end{array}$ & $\begin{array}{r}10.94 \\
0.54 \\
8.12\end{array}$ & $\begin{array}{l}0.499 \\
0.037 \\
0.378\end{array}$ & $\begin{array}{l}29.2 \\
19.4 \\
28.6\end{array}$ & $\begin{array}{l}413 \\
416 \\
413\end{array}$ & $\begin{array}{r}358 \\
87 \\
427\end{array}$ & $\begin{array}{r}34 \\
2204 \\
34\end{array}$ \\
\hline 6 & $\begin{array}{c}\text { late } \\
\text { Cenomanian }\end{array}$ & $\begin{array}{l}-6-1(13-14) \\
-6-1(81-83) \\
-6-2(141-143) \\
-6-3(76-78)\end{array}$ & $\begin{array}{l}71 \\
80 \\
79 \\
76\end{array}$ & $\begin{array}{l}0.05 \\
0.04\end{array}$ & $\begin{array}{l}0.009 \\
0.007\end{array}$ & $\begin{array}{l}8.1 \\
9.0\end{array}$ & n.d. & 0 & 1925 \\
\hline 7 & $\begin{array}{c}\text { Age } \\
\text { uncertain }\end{array}$ & $-9-3(95-96)$ & 89 & & & & & & \\
\hline
\end{tabular}

Note: Column beadings, order of samples, and abbreviations as in Table 2.

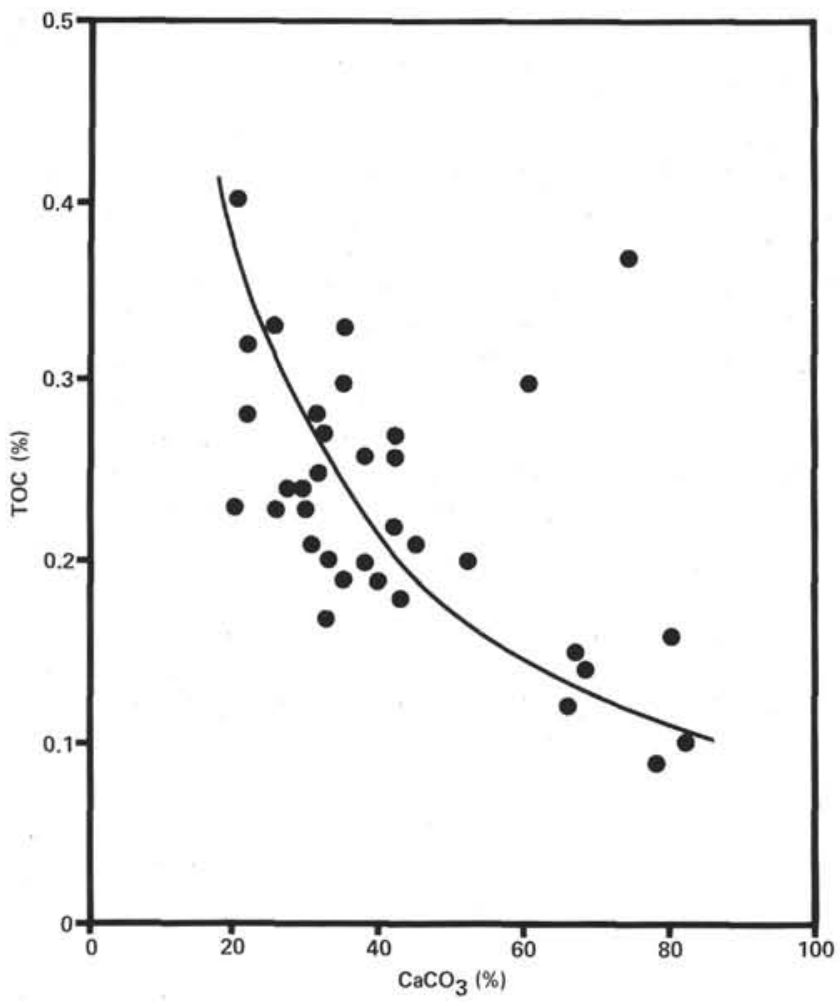

Figure 9. TOC versus $\mathrm{CaCO}_{3}$ content for Holocene and Pleistocene sediments (Core 1) at Site 551.

drogen indices ( $\approx 390 \mathrm{mg} \mathrm{HC} / \mathrm{g}$ TOC) of the black shale are the highest encountered on this leg, and indicate that the organic matter is of mixed terrestrial and marine origin.

The black shale at Site 551 is a carbonaceous claystone rich in silica and zeolites, and it contains an abundance of radiolarian fragments. Carbonate was not detected in the black shale, whereas the sediments in the lithologic units above and below it are carbonate rich.

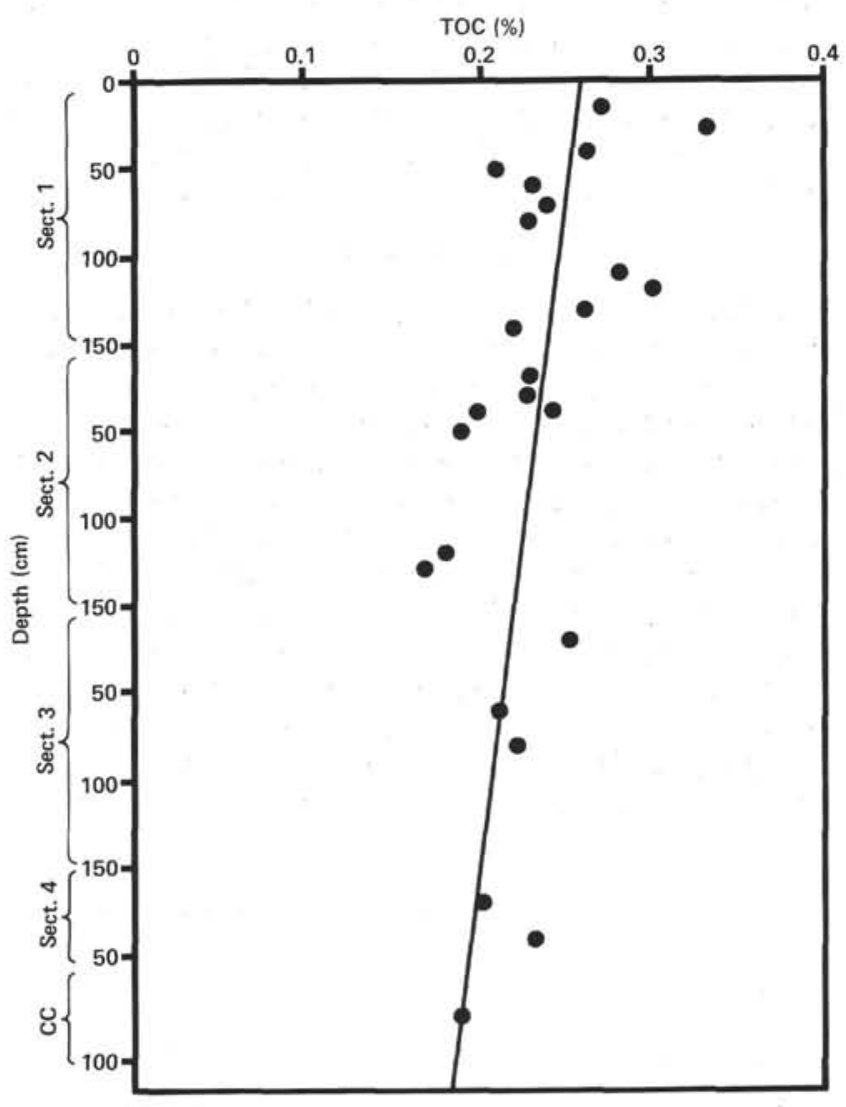

Figure 10. TOC versus depth for samples having 26 to $45 \% \mathrm{CaCO}_{3}$. Site 551, Core 1.

\section{DISCUSSION}

\section{Carbonate Contents, TOC Values, and Sediment} Accumulation Rates

The data in Figures 2 and 9 show that the TOC values of the Site 548 and 551 sediments are inversely proportional to carbonate content. At Sites 549 and 550, fur- 
thermore, the most calcareous samples consistently have the lowest TOC values. Several factors may contribute to this trend, including sediment type, accumulation rate, and diagenesis.

\section{Sediment Type}

The inverse relationship between carbonate content and TOC could be explained if the calcareous components contributed much less organic matter to the sediments than the clastic fraction. The inverse relationship between $\mathrm{TOC}$ and $\mathrm{CaCO}_{3}$ content even within each lithologic unit at Site 548 (Fig. 2) supports this interpretation. Sediment type is not the only factor that influences TOC, however, because within each range of carbonate content TOC decreases with increasing burial depth (Fig. 2).

\section{Sediment Accumulation Rate}

Other things being equal, organic carbon is preserved most efficiently when sediment accumulation rates are highest, because under these circumstances the organic matter is removed most rapidly from the sediment surface, the zone of the most intense microbial activity (Heath et al., 1977; Müller and Suess, 1979; Ibach, 1982). This relationship is apparent at Site 548 (Fig. 11).

\section{Microbial Diagenesis}

Because microbial diagenesis is a function of both time and the availability of nutrients and electron acceptors, it is not easy to separate the effects of organic carbon diagenesis and sediment accumulation rate. Figure 11 suggests that diagenesis was indeed inhibited by rapid burial near the sediment/water interface at Site 548. The diagenetic transformation of organic matter is not limited to the zone of macrofaunal activity, however. Waples and Sloan (1980) showed that in a Pacific Ocean setting in which the depositional environment had remained constant for 15 m.y., carbon and nitrogen decreased exponentially with depth of burial as a result of diagenesis within the sediments. Claypool (in press) attributed an exponential decrease in TOC in Leg 78A sediments to

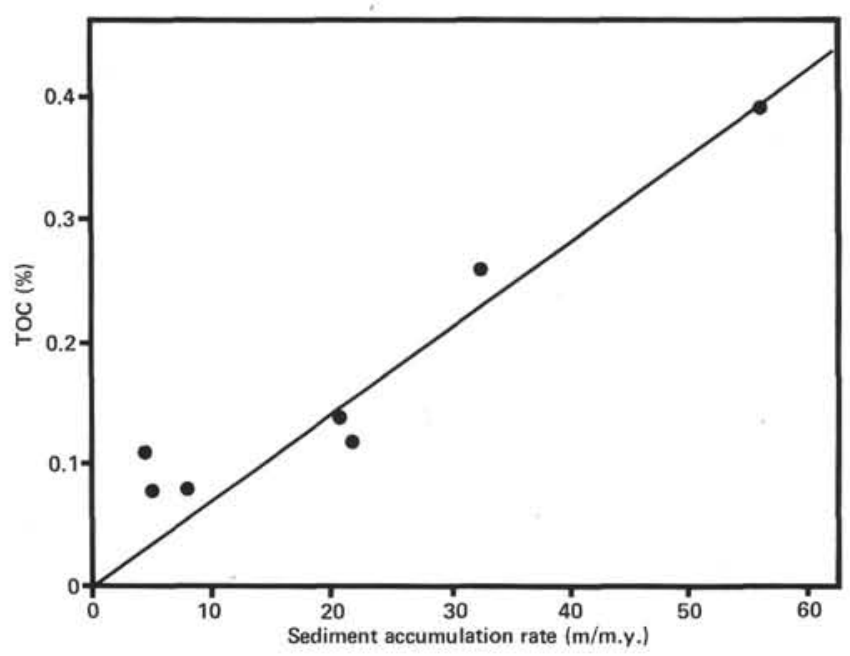

Figure 11. TOC versus sediment-accumulation rates for different lithologic units and subunits, Site 548. diagenesis. The exponential decrease apparent in Figure 1 is similar to that observed by Waples and Sloan and by Claypool.

\section{Kinetics of Organic Carbon Diagenesis}

In Figures 1 and 10 the effects of differing sedimentation rates on organic diagenesis have been largely removed by averaging several samples (Fig. 1) or by limiting the samples to a narrow range of carbonate contents (Fig. 10). Because the exact age of the short interval sampled at Site 551 could not be determined, kinetic analysis of the data was not attempted. At Site 548, however, a semilog plot of TOC versus sediment age gave a straight line (Fig. 12), indicating that the diagenesis of organic carbon is a first-order process. The rate constant obtained $(4.0 / \mathrm{m} . \mathrm{y}$.) is 3 to 5 times higher than that reported by Waples and Sloan (1980) for comparable organic-carbon-lean hemipelagic sediments in the Pacific (Leg 58). The reasons for the differences in the diagenesis rate constants between that Atlantic and Pacific sediments are not obvious. However, they may be related to (1) a greater influx of reactive (marine) organic matter in the Atlantic sediments, (2) the much longer water column at the Pacific sites (which would lead to more oxidation prior to arrival at the seafloor), or (3) deposition below the CCD in the Pacific but above it in the Atlantic.

These results lend further support to the relatively new idea that microbial transformations are important even at burial depths of several hundred meters, and in sediments that have been buried for several million years. Rates of diagenesis are very modest in deep-sea sediments that have low organic carbon contents, but even relatively oxidized organic matter eventually seems to be susceptible to extensive bacterial degradation.

\section{Paleoenvironments}

The dominant depositional environment for most of the sediments recovered on Leg 80 was pelagic, with water depths ranging from upper bathyal to abyssal. Phyto-

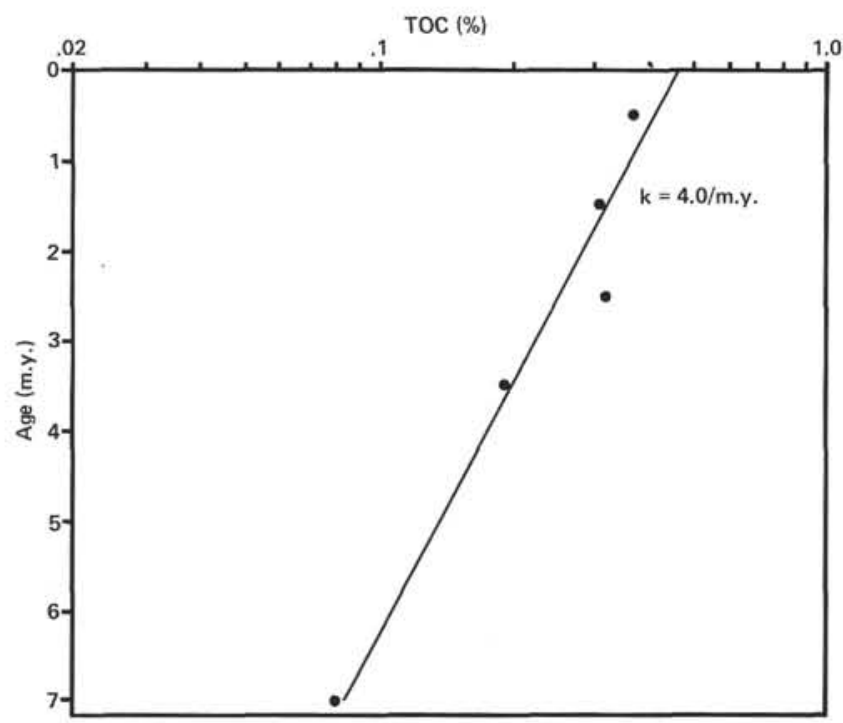

Figure 12. Semilog plot of TOC versus sediment age, Site 548 . Values are averaged over 1.0 -m.y. intervals. $\mathrm{CaCO}_{3}=26$ to $45 \%$. 
plankton productivity was apparently rather modest, because the rate of accumulation of biogenic material is low and the siliceous organisms associated with zones of high productivity in modern oceans are generally absent. Little terrestrial influence is found in most of the Cretaceous and Tertiary chalks, a consequence of the flat relief on land and the distance of the sites from the ancient shoreline. The organic matter preserved in the pelagic chalks is of terrestrial origin (Type III kerogen) and is highly oxidized and refractory. Algal organic matter undoubtedly reached the bottom attached to the ubiquitous tests of calcareous nannoplankton and foraminifers but was apparently completely oxidized during early diagenesis. Sediment accumulation rates were generally rather low (Fig. 11), and the bottom waters must in general have been well oxygenated. There is a consistent relationship between organic carbon content and degree of oxidation, as shown by a plot of TOC versus oxygen index for the Site 550 sediments (Fig. 13).

\section{Terrestrial Influence}

This general pattern of pelagic sedimentation was broken on several occasions, however. Sedimentation dur-

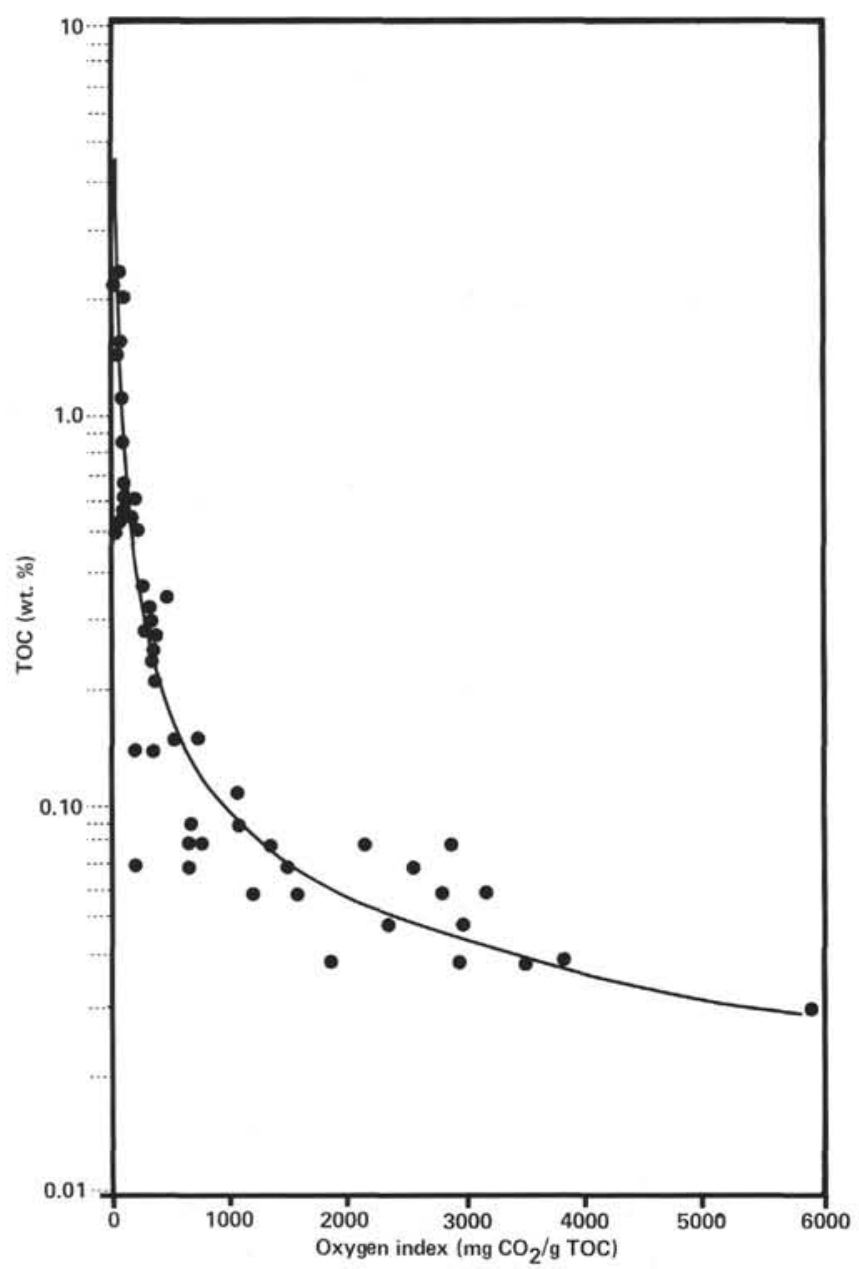

Figure 13. TOC versus oxygen index. Site 550 sediments (all lithologic units). ing the Pleistocene and Holocene was more terrestrially dominated than during the Tertiary or Mesozoic because of the lower sea levels associated with continental glaciation. During these periods of hemipelagic sedimentation, some deposits occurred as turbidite flows, and relatively rapid burial produced higher organic carbon contents.

The sediments with the most pronounced terrestrial contribution, however, were deposited at Site 549 on a shallow shelf during the rifting phase (middle Albian to Barremian: Cores 32-93). Large pieces of woody and leafy debris are plentiful and in fact represent most of the preserved organic matter. The hydrogen indices are low $(\approx 100 \mathrm{mg} \mathrm{HC} / \mathrm{g} \mathrm{TOC})$, indicating that the organic matter in these sediments is of terrestrial origin (Type III).

These sediments are extensively bioturbated, indicating deposition in a well oxygenated environment. The presence of local concentrations of pyrite of both microscopic and macroscopic size indicates that reducing microenvironments existed within the sediment in the vicinity of large organic particles; it does not imply an anoxic water column above these sediments. The richness of these sediments in organic carbon is a result of the coarse size, rapid deposition, and poor biodegradability of the wood and leaf fragments.

High $\mathrm{C} / \mathrm{N}$ ratios also support the hypothesis that almost all the organic matter preserved in the sediments (except the Cenomanian black shales at Sites 549 and 551 ) is of terrestrial origin. Because woody plants are much lower in nitrogen than herbaceous plants or phytoplankton, woody material has distinctively high $\mathrm{C} / \mathrm{N}$ ratios (Waples, 1977). A sample of pure fossil wood (Core 57 , Section $1,111 \mathrm{~cm}$ ) was found to have an atomic $\mathrm{C} / \mathrm{N}$ ratio of 90 . Other samples that contained both woody debris and clay minerals had values as high as 89 (Table 2). The lower $\mathrm{C} / \mathrm{N}$ ratios in the samples rich in clay are attributed to the presence of inorganic nitrogen adsorbed on the clay surfaces as ammonia or ammonium ions (Waples, "Nitrogen," this volume).

\section{Marine Influence}

Several layers at Sites 549 and 551 are depleted in carbonate and enriched in siliceous material of probable biogenic (radiolarian) origin. The siliceous layers probably represent periods of high marine productivity. At Site 551, for example, the sediments in Core 5, Section 2 (3-11 and 49-52 cm) are rich in opal CT and are coarse grained, probably as a result of the diagenesis of silica, but they show no other unusual sedimentological characteristics. Like the surrounding marly chalk, the sediments are light green and apparently highly oxidized. In many of the layers rich in silica, therefore, there is no evidence of unusually high preservation of organic carbon.

Section $1(43-49 \mathrm{~cm})$ of Core 5 (Site 551) also contains an interval that is poor in carbonate. Fine olive yellow layers alternate with whitish laminae on a submillimeter scale (Plate 1). The laminae resemble varves and appear to be identical to fine laminae observed in areas of high productivity today, such as the Gulf of California. Clays are dominant and probably account 
for the darker laminae. Silica is also present, mainly as low cristobalite and quartz. In contrast to modern laminated sediments, however, organic carbon contents are very low: the two samples analyzed contain less than $0.1 \% \mathrm{TOC}$ and are thus indistinguishable from the other oxidized sediments. If the original laminae had been preserved in an anoxic environment, much more organic carbon would also have been preserved. The organic matter must therefore have been lost by diagenetic oxidation after burial.

Analogs of this situation are found in other finely laminated sediments. The diatomaceous deposits of the Sisquoc Formation near Lompoc, California, are finely laminated on the same scale but are nearly white and generally contain less than $0.2 \%$ TOC. The occasional dark zones interbedded with the white ones contain $2 \%$ TOC or more.

If the organic-carbon-lean, laminated sediments at Site 551 were oxidized after deposition through the percolation of oxygenated water, it is likely that these waters came laterally or from above, because the organic-carbon-rich black sediments below have not been affected. The thinness of the laminated olive zone (about $6 \mathrm{~cm}$ ) may have allowed it to be completely oxidized. The other thin siliceous zones in Core 5, Section 2 may have suffered the same fate. Loss of the contact between the organic-carbon-rich black sediments and the overlying lighter colored material prevents us from seeing clearly what effects oxygenated meteoric waters might have had at the top of the black sediments.

\section{Black-Colored Sediments}

\section{Late Cenomanian to Earliest Turonian}

Coeval black-colored sediments of late Cenomanian to earliest Turonian age, slightly to highly enriched in organic matter, were recovered at Sites 549 and 551. The earliest nonfossiliferous sediments of Unit 4 at Site 550 may also be of late Cenomanian or Turonian age. Site 548 was apparently emergent at this time and therefore did not yield any sediments of Cenomanian age. Lithologic and geochemical data on the black sediments are compared in Table 5 .

The black late Cenomanian or earliest Turonian sediments at Sites 549 (Unit 5) and 551 (Unit 4) are very sim-

Table 5. Comparison of organic geochemical data for black sediments from Sites 549, 550, and 551.

\begin{tabular}{|c|c|c|c|c|c|c|c|c|}
\hline \multirow[b]{2}{*}{ Hole } & \multirow[b]{2}{*}{ Core } & \multirow[b]{2}{*}{ Age } & \multirow[b]{2}{*}{$\underset{(\%)}{\mathrm{CaCO}_{3}}$} & \multirow[b]{2}{*}{$\begin{array}{l}\text { TOC } \\
(\%)\end{array}$} & \multirow[b]{2}{*}{$\begin{array}{l}\text { Biogenic } \\
\text { silica }\end{array}$} & \multirow[b]{2}{*}{$\begin{array}{c}\text { Atomic } \\
\mathrm{C} / \mathrm{N}\end{array}$} & \multicolumn{2}{|c|}{ Rock-Eval } \\
\hline & & & & & & & $\begin{array}{c}\mathrm{H}- \\
\text { index }\end{array}$ & $\begin{array}{c}\text { O- } \\
\text { index }\end{array}$ \\
\hline 551 & 5 & earliest Turonian & 0 & 9.5 & Abundant & 29 & 390 & 34 \\
\hline 549 & 27 & late Cenomanian & 20 & 3.4 & Abundant & 26 & 317 & 38 \\
\hline $550 \mathrm{~B}$ & $13-14$ & $\begin{array}{l}\text { Santonian or } \\
\text { Coniacian, } \\
\text { possibly to } \\
\text { Turonian }\end{array}$ & 2 & 0.5 & Absent & 16 & 25 & 125 \\
\hline $550 \mathrm{~B}$ & $16-18$ & $\begin{array}{l}\text { middle to early } \\
\text { Cenomanian }\end{array}$ & 65 & 2.0 & Absent & 22 & 270 & 75 \\
\hline $550 \mathrm{~B}$ & $24-25$ & $\begin{array}{l}\text { middle to early } \\
\text { Cenomanian }\end{array}$ & 55 & 1.7 & Absent & 22 & 220 & 65 \\
\hline 549 & $91-93$ & Barremian & 0 & 4.0 & Absent & 75 & 140 & 125 \\
\hline
\end{tabular}

Note: Hydrogen and oxygen indices as in Table 1. Gaps in Hole 550B core sequence represent lithologies other than black sediments. ilar to each other in nearly all respects, whereas those from Site 550 are different. Those at Sites 549 and 551 are laminated, low in carbonate, high in biogenic silica, rich in organic carbon, and have hydrogen indices between 300 and 400 . The Core 13-14 sediments at Site 550, in contrast, are homogeneous or bioturbated, devoid of carbonate, low in biogenic silica, and have comparatively low TOC values and hydrogen indices.

Sediment color in Unit 4 at Site 550 (which is similar to the coeval "multicolored claystones" of Arthur [1979a]) is closely related to organic carbon content (Fig. 6). The black sediments have the highest TOC values (up to $0.67 \%$ ), followed by the very dark gray, grayish olive green, gray, and brown and red sediments. Because the black color of the darkest sediments is too intense to be caused solely by the small amounts of organic carbon present, we suggest that pyrite (noted in smear slides), formed under strongly reducing conditions within the sediment, is mainly responsible. The overlying green claystones may thus owe their color to the presence of reduced iron $\left(\mathrm{Fe}^{2+}\right)$ in the absence of sulfide. The brown and red sediments above the green claystones were probably stained with $\mathrm{Fe}^{3+}$ oxides. This color sequence is therefore consistent with the interpretation that as oxygen levels in the sediments increased, organic carbon content decreased.

The total Rock-Eval hydrocarbon yields for samples from the oxic and anoxic late Cenomanian-earliest Turonian facies at Sites 549 and 550 show a direct correlation to TOC (Fig. 14). Only after the TOC content of the samples rises above $1 \%$ does the relationship become linear, however. The same results have been observed by Kendrick (1982) and Peters and Simoneit (1982) for immature sediments from the Gulf of California. They attributed the nonlinearity in the low-TOC range either to the adsorption of the pyrolytic hydrocarbons by the kerogen or mineral matrix or to a change in the organic matter type at TOC values less than $1 \%$. A similar relationship has been noted between TOC and organic nitrogen (Waples, "Nitrogen," this volume). Sediments that contained less than $1 \%$ TOC had lower contents of nitrogen than would have been expected by extrapolating the high-TOC samples, suggesting that the effects of diagenesis on the preserved organic matter were much different under oxic and anoxic conditions.

\section{Early and Middle Cenomanian}

At Site 550 the early and middle Cenomanian black, laminated organic-carbon-rich sediments (Cores 24-25 and $16-18$, respectively) are similar to those at Sites 549 and 551 (Table 5). These sediments are relatively high in carbonate and low in biogenic silica, and they have TOC values and hydrogen indices that lie between those for the homogeneous Site 550 and laminated Site 549 and 551 late Cenomanian to earliest Turonian black sediments. The black laminated horizons alternate on a decimeter scale with gray to white, homogeneous, organic-carbonlean sediments of similar lithology.

No early to middle Cenomanian black sediments were recovered at the other sites. Site 548 was emergent at that time, and no sediment accumulated at Site 551 (or 


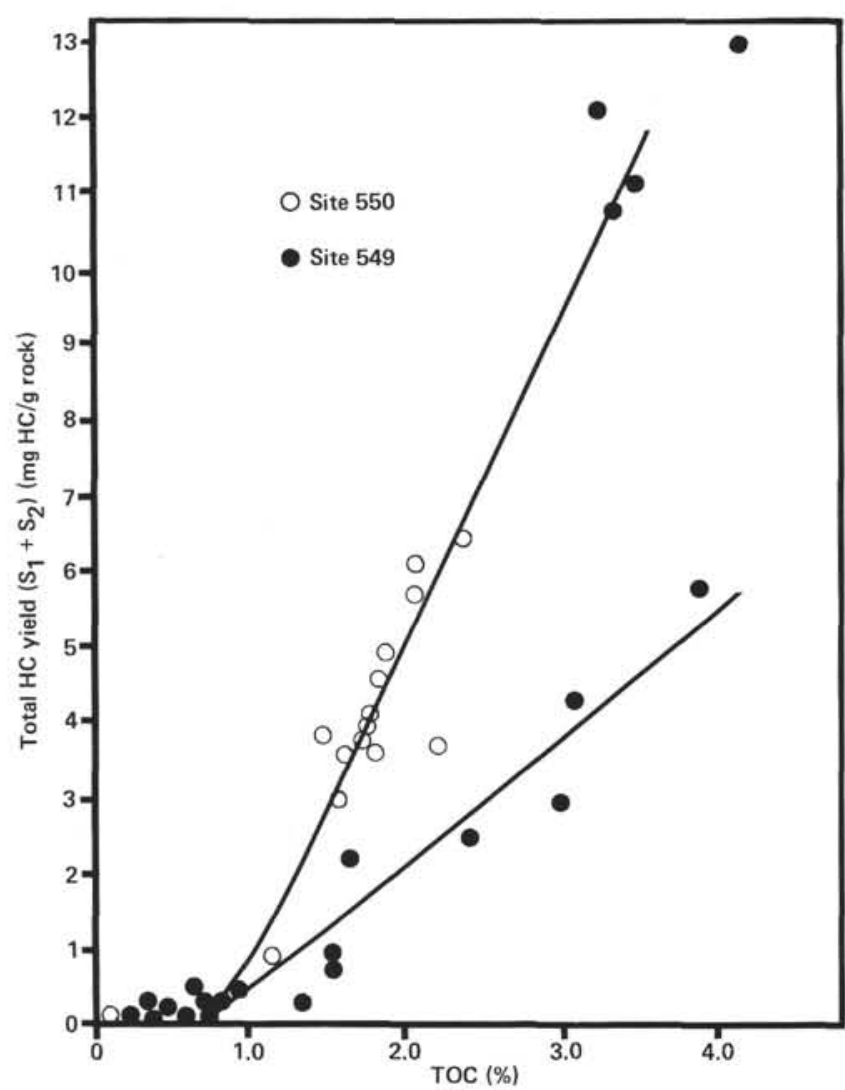

Figure 14. Total hydrocarbon-generation potential (Rock-Eval $\mathrm{S}_{1}+$ $\mathrm{S}_{2}$ ) for late Cenomanian black sediments from Sites 549, 550, and 551 and for early to middle Cenomanian black sediments from Site 550 .

else it eroded away before the late Cenomanian). The absence of black sediments at Site 549 could be explained by either the shallowness of the water during the early and middle Cenomanian or the poor recovery of the condensed section present.

\section{Depositional Model}

The following model is proposed to explain the variations among these black sediments and the differences in the timing of the deposition of the laminated, organic-carbon-rich sediments at the three sites. The whitish early and middle Cenomanian sediments recovered at Site 550 were deposited under highly oxidizing conditions in well aerated waters. These sediments supported a benthic fauna, including burrowing organisms, that caused nearly all the available organic matter to decompose. Light gray, gray, and dark gray, homogeneous or bioturbated sediments represent successively lower levels of bottom water oxygenation and benthic faunal activity. The very dark, weakly laminated to faintly bioturbated sediments were probably deposited under conditions of oxygen levels of $0.5 \mathrm{ml} / 1$ or less, where benthic faunal activity was severely restricted. The black laminated sediments were laid down in water that was almost totally depleted in oxygen at the bottom (oxygen levels of $0.2 \mathrm{ml} / 1$ or less).

It is unlikely, however, that the bottom waters at Site 550 ever became totally anoxic, both because the TOC values are relatively low in comparison with the other black laminated sediments and because much of the organic material is apparently terrestrial in origin and therefore less effective than marine organic matter in consuming dissolved oxygen. Furthermore, the laminated sediments represent only a tiny fraction of the middle Cenomanian section, indicating that oxic conditions predominated.

Organic carbon contents and benthic organisms in these middle Cenomanian sediments were influenced inversely by the same factor, oxygen, so that low TOC values correspond to high levels of bioturbation. At TOC values greater than $1 \%$, however, burrows become much scarcer, and they essentially disappear when the TOC values reach about $1.5 \%$. Changes in sediment color in Unit 5 at Site 550 correlate well with the changes in the oxygen and hydrogen indices (Fig. 15), indicating that benthic faunal activity significantly altered the chemical composition of the sedimentary organic matter.

The oxygen indices decrease consistently from the white, red, and brown, obviously well oxidized samples to the gray and black, less well oxidized samples. The hydrogen indices show the opposite trend, increasing dramatically in the dark gray and black samples. An imprint of the oxygenation (redox) conditions in the uppermost sediments at the time of deposition is thus preserved in the sedimentary organic matter. This trend is, of course, only valid for sediments that have not undergone significant catagenesis; once thermal cracking of the organic matter begins, the redox imprint gradually disappears.
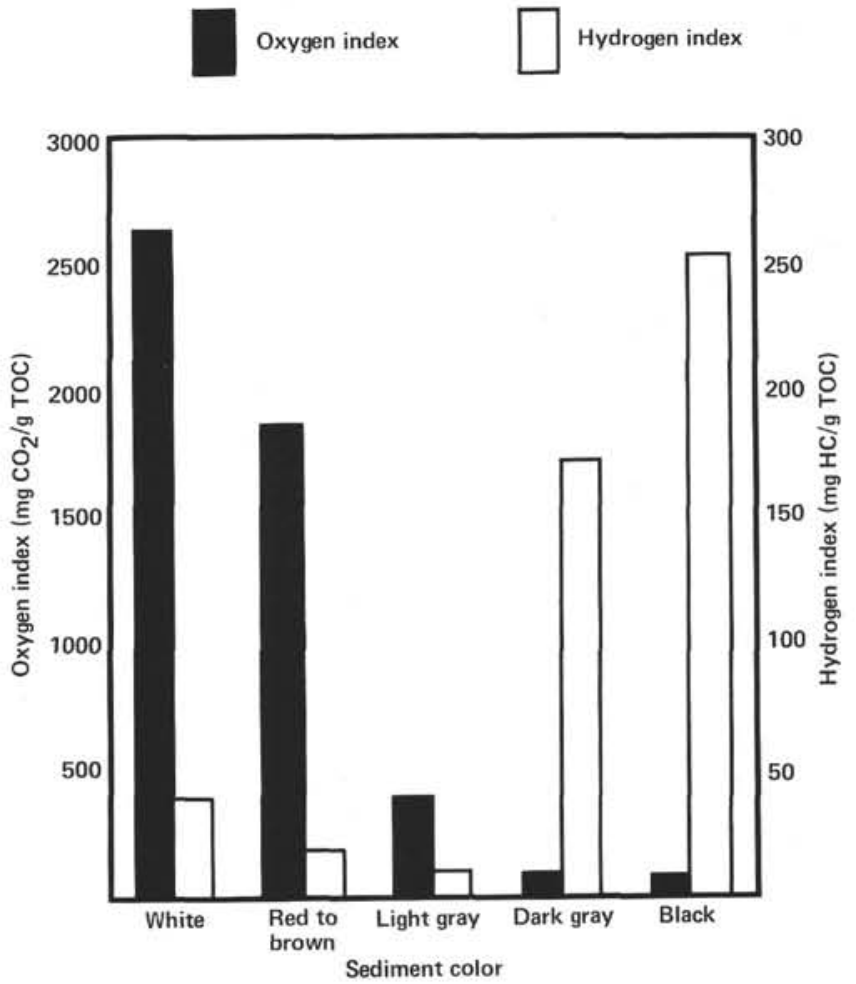

Figure 15. Hydrogen and oxygen indices as a function of sediment color, Site 550, Unit 5. Values are averaged for all samples of each color. 
There are several possible explanations for the inferred cyclical changes in oxygen levels in the Cenomanian sediments at Site 550. One possibility is that the bottom waters were continuously anoxic or nearly anoxic and that at least some of the light-colored layers represent rhythmic pulses of sediment that were emplaced relatively quickly by density flows.

A second interpretation (and the one we prefer) is that pelagic deposition was dominant, with minor contributions from flows or turbidites playing no essential role in determining oxygen levels. Oxygen levels in bottom waters would have fluctuated from rather high to nearly zero, perhaps in response to changes in sea level, productivity, or circulation patterns. Relatively rapid fluctuations in oxygen levels have been documented for sediments deposited within oxygen-minimum layers on continental slopes (Govean and Garrison, 1981). Two periods of relatively low oxygen levels are suggested by the high TOC values in portions of Cores 24 to 25 and Cores 16 to 18 (Table 3 and Fig. 5), but even within these intervals there was considerable fluctuation.

Changes in circulation seem more likely to be the major cause of oxygenation cycles in the early and middle Cenomanian than changes in productivity, because the early period of carbon enrichment (Cores 24-25) is characterized by lower than average levels of carbonate content (Table 3). Furthermore, there is no evidence of an increase in biogenic silica at these times. Some time in the middle or late Cenomanian the carbonate compensation depth (CCD) rose, possibly in response to an accumulation of organic carbon earlier in the Cenomanian (Waples, "Anoxia," this volume). Noncalcareous sediments were thus deposited in deep water (Unit 5, Site 549).

Another period of oxygen depletion then occurred in the late Cenomanian, the period when black sediments were deposited at Sites 549,550 , and 551 within an expanded oxygen-minimum layer (Fig. 16). The sediments in Unit 4 at Site 550 were deposited at lower bathyal depths, probably near the lower limit of the expanded oxygen-minimum layer. The very low sediment accumulation rate brought about by carbonate dissolution below the CCD prevented the oxygen levels from reaching

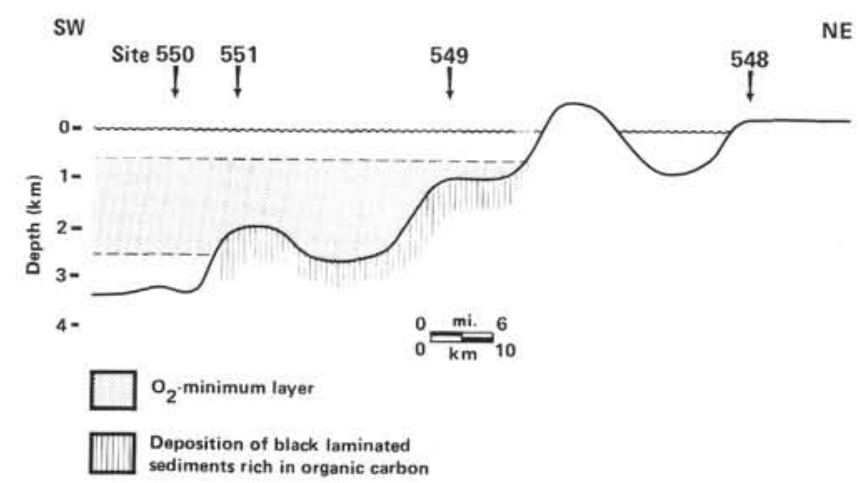

Figure 16. Deposition of late Cenomanian black sediments at Sites 549,550 , and 551 within an expanded oxygen-minimum layer. The position of the Leg 80 sites with respect to sea level is as envisioned for the late Cenomanian and earliest Turonian. the low values that prevailed at Site 550 in the early and middle Cenomanian. In contrast, the coeval black laminated sediments from Sites 549 and 551 were deposited in shallower water, nearer the upper part and middle of the oxygen-minimum layer, respectively (Fig. 16). The lower oxygen contents of the waters at the latter two sites fostered the greater preservation of organic matter.

The more shoreward locations of Sites 551 and 549 may also have been regions of greater photosynthetic productivity, which would have led to a greater influx of marine organic matter to the sediments. Increased productivity was probably much more important in producing the laminated organic-carbon-rich sediments during the late Cenomanian than during the early and middle Cenomanian. The paucity of biogenic silica in the late Cenomanian black sediments from Site 550 suggests that at that site no important change in productivity was related to the enhanced preservation of organic matter. At Sites 549 and 551, on the other hand, the late Cenomanian to earliest Turonian black sediments are much more siliceous than the organic-carbon-lean sediments immediately above and below. This fact strongly suggests a cause and effect relationship at these sites between the production of siliceous organisms and anoxia in the bottom water.

Although there is an imperfect correlation in the modern oceans between the intensity of primary productivity and the degree of preservation of organic matter in sediments (Demaison and Moore, 1980; Demaison, 1981), most areas in which surface productivity is very high also have well developed oxygen-minimum layers. Wherever an intense oxygen-minimum layer intersects the sediment/water interface, the preservation of organic matter in black laminated sediments is excellent (e.g., the Gulf of California; Calvert, 1964).

We believe that a sudden and dramatic productivity increase, as indicated by the sudden proliferation of biogenic silica, caused the accumulation of the black laminated sediments at Sites 549 and 551 . We suggest that the proliferation was the result of local upwelling at the intersection of an oxygen-minimum layer with the outer continental shelf or an upper slope. Ocean-wide anoxia would not be necessary to produce these black sediments.

As productivity eventually began to wane in the early Turonian, the bottom waters and the underlying muds became more oxic and the CCD began to sink. Lightcolored, oxidized calcareous sediments were deposited at Sites 549 and 551. At Site 550, which was still below the $\mathrm{CCD}$, the clays became progressively more oxidized, and the green and red claystones of Unit 4 were deposited. Green clays were formed in this first stage of ventilation of bottom waters as iron was reduced to $\mathrm{Fe}^{2+}$, but lack of sulfide (as a result of minimal sulfate reduction) in the sediments prevented the formation of abundant pyrite. As the oxygen levels in the bottom waters eventually became higher in the Coniacian and Santonian, $\mathrm{Fe}^{2+}$ was oxidized to $\mathrm{Fe}^{3+}$, resulting in the deposition of the brown clays and the reddish staining of greenish gray clays. A final hiatus in Core 13 (Hole 550B) prevents us from seeing the end of this cycle, which probably occurred after the Atlantic Ocean had become large 
enough to allow much freer circulation of bottom waters. Anoxia thus ceased permanently at Site $\mathbf{5 5 0}$.

Many of the fluctuations in the oxygen levels of bottom waters recorded in the sedimentary records at these three sites are probably partly a consequence of the location of each of the sites on topographic highs. The intervening topographic lows might well have accumulated sediments that recorded a more continuous history of low oxygen levels in the Goban Spur area during the Cenomanian and early Turonian.

The black sediments at Sites 549, 550, and 551 may correspond to other late Cenomanian and Turonian black shales recovered from previous DSDP drill sites in the North Altantic. The formation of these sediments has been attributed to "oceanic anoxic events" that occurred at various times in the Cretaceous, and which may have been due primarily to restrictions in circulation (Schlanger and Jenkyns, 1976; Arthur, 1979b; Jenkyns, 1980). This question is discussed in more detail elsewhere (Waples, "Anoxia," this volume).

\section{Oil Source Potential}

The extremely low TOC values and hydrogen indices indicate clearly that virtually the entire sedimentary section at all four sites is devoid of oil or gas source potential. There are a few exceptional horizons, however.

\section{Late Cenomanian to Earliest Turonian Black Sediments}

The late Cenomanian to earliest Turonian laminated black sediments at Sites 549 and 551 have very good to excellent oil and gas source potential; the TOC values are high and the hydrogen indices are moderately high (Table 5). The organic matter is of mixed marine and terrestrial origin (kerogen Types II and III). Thermal maturity is low, as indicated by the low $T_{\max }$ values that are obtained during Rock-Eval pyrolysis (approximately $\left.420^{\circ} \mathrm{C}\right)$.

The homogeneous or bioturbated black sediments of equivalent age at Site 550 have much lower oil and gas source potential. Both the TOC values and the hydrogen indices (Table 5) indicate that the quantity and the degree of preservation of the organic matter are much lower than in the coeval laminated sediments. These sediments are also thermally immature.

\section{Early to Middle Cenomanian Black Sediments}

Because the TOC values and the hydrogen indices of the early to middle Cenomanian laminated sediments are lower than those of the laminated late Cenomanian to earliest Turonian sediments (Table 5), the oil and gas source potential of the former is somewhat lower. Thermal maturity (as indicated by the Rock-Eval $T_{\max }$ ) is low in these sediments. It is unlikely that the black sediments in the Goban Spur area have achieved thermal maturity even in the topographic lows, where the sediment pile is thicker. Much deeper burial would be required, even given the reasonably high heat flows measured for the region. Only if substantial heating by igneous activity had taken place could thermal maturity have been achieved.

\section{Barremian to Albian Sublittoral to Upper Bathyal Sediments}

Oil and gas source potential are low for the Barremian to Albian Site 549 sediments. High TOC values for some samples (Table 2) are largely an artifact of sampling. The hydrogen indices are very low (generally $<50$ ). Only the earliest sediments (Cores 85-92) have slightly higher hydrogen index values $($ maximum $=152$ ) and might have some gas or slight oil source potential. Thermal maturity, however, is uniformly quite low.

\section{ACKNOWLEDGMENT}

We thank Jim Stinnett and Peter Kroopnick for reviewing the manuscript and Mobil Research and Development Corporation and Exxon Production Research for permission to publish this work.

\section{REFERENCES}

Arthur, M. A., 1979a. Origin of Upper Cretaceous multicolored claytones of the western Atlantic. In Tucholke, B. E., Vogt, P. R., et al., Init. Repts. DSDP, 43: Washington (U.S. Govt. Printing Office), 417-420.

1979b. North Atlantic Cretaceous black shales: the record at Site 398 and a brief comparison with other occurrences. In Sibuet, J. C., Ryan, W. B. F., et al., Init. Repts. DSDP, 47, Pt. 2: Washington (U.S. Govt. Printing Office), 719-751.

Bode, G. W., 1973. Appendix II. Carbon and carbonate analyses, Leg 15. In Edgar, N. T., Saunders, J. B., et al., Init. Repts. DSDP, 15: Washington (U.S. Govt. Printing Office), 1129-1137.

Calvert, S. E., 1964. Factors affecting distribution of laminated diatomaceous sediments in Gulf of California. In van Andel, T. H., and Shor, G. G., Jr. (Eds.), Mem. Am. Assoc. Pet. Geol., 3:311-330.

Claypool, G. E., in press. Diagenesis of organic matter, isotopic composition of calcite veins in basement basalt and pore water in sediment-Barbados Ridge complex, Deep Sea Drilling Project Leg 78A. In Biju-Duval., B., Moore, J. C., et al., Init. Repts. DSDP, 78A: Washington (U.S. Govt. Printing Office).

Clementz, D. M., Demaison, G. J., and Daly, A. R., 1979. Well site geochemistry by programmed pyrolysis. Proc. 11th Annual Offshore Technology Conf., Houston, pp. 465-470.

Demaison, G. J., 1981. Oil source bed deposition and occurrence on active continental margins. In Douglas, R. G., Colburn, I. P., and Gorsline, D. S. (Eds.), Depositional Systems of Active Continental Margin Basins: Short Course Notes. SEPM Short Course, pp. $157-165$.

Demaison, G. J., and Moore, G. T., 1980. Anoxic environments and oil source bed genesis. Org. Geochem., 2:9-31.

Deroo, G., Herbin, J. P., Roucaché, J., and Tissot, B., 1979a. Organic geochemistry of Cretaceous shales from DSDP Site 398, Leg 47B, eastern North Atlantic. In Sibuet, J. C., Ryan, W. B. F., et al., Init. Repts. DSDP, 47, Pt. 2: Washington (U.S. Govt. Printing Office), 513-522.

$1979 \mathrm{~b}$. Organic geochemistry of Cretaceous mudstones and marly limestones from DSDP Sites 400 and 402 , Leg 48 , eastern North Atlantic. In Montadert, L., Roberts, D. G., et al., Init. Repts. DSDP, 48: Washington (U.S. Govt. Printing Office), 921-930.

Espitalié, J., Laporte, J. L., Madec, M., Marquis, F., Leplat, P., Poulet, J., and Boutefeu, A., 1977. Méthode rapide de caracterisation des roches mères, de leur potential pétrolier et de leur degré d'évolution. Rev. Inst. Fr. Pet., 32:23-42.

Govean, F. M., and Garrison, R. E., 1981. Significance of laminated and massive diatomites in the upper part of the Monterey Formation, California. In Garrison, R. E., and Douglas, R. G. (Eds.), The Monterey Formation and Related Siliceous Rocks of California. Spec. Publ. Soc. Econ. Paleontol. Mineral., pp. 181-198.

Heath, G. R., Moore, T. C., Jr., and Dauphin, J. P., 1977. Organic carbon in deep-sea sediments. In Andersen, N. R., and Malahoff, A., (Eds.), The Fate of Fossil Fuel $\mathrm{CO}_{2}$ in the Oceans: New York (Plenum), pp. 605-625. 
Ibach, L. E. J., 1982. Relationship between sedimentation rate and total organic carbon content in ancient marine sediments. Am. Assoc. Pet. Geol. Bull., 66:170-188.

Jenkyns, H. C., 1980. Cretaceous anoxic events: from continents to oceans. J. Geol. Soc. London, 137:171-188.

Kendrick, J. W., 1982. Petroleum-generating potential of sediment in the Gulf of California. In Curry, J. R., Moore, D. G., et al., Init. Repts. DSDP, 64, Pt. 2: Washington (U.S. Govt. Printing Office), 871-876.

Müller, P. J., and Suess, E., 1979. Productivity, sedimentation rate, and sedimentary organic matter in the oceans-1. Organic carbon preservation. Deep Sea Res., 26A:1347-1362.

Peters, K. E., and Simoneit, B. R. T., 1982. Rock-Eval pyrolysis of Quaternary sediments from Leg 64, Sites 479 and 480, Gulf of Cal- ifornia. In Curray, J. R., Moore, D. G., et al., Init. Repts. DSDP, 64, Pt. 2: Washington (U.S. Govt. Printing Office), 925-932.

Schlanger, S. O., and Jenkyns, H. C., 1976. Cretaceous oceanic anoxic events: causes and consequences. Geol. Mijnbouw, 55:179-184.

Waples, D. W., 1977. C/N ratios in source rock studies. Miner. Ind. Bull. Colo. Sch. Mines, 20(5).

Waples, D. W., and Sloan, J. R., 1980. Carbon and nitrogen profiles in deep-sea sediments: new evidence for bacterial diagenesis at great depths of burial. In Klein, G. deV., Kobayashi, K., et al., Init. Repts. DSDP, 58: Washington (U.S. Govt. Printing Office), 745-754.

Date of Initial Receipt: December 7, 1982 Date of Acceptance: July 1, 1983

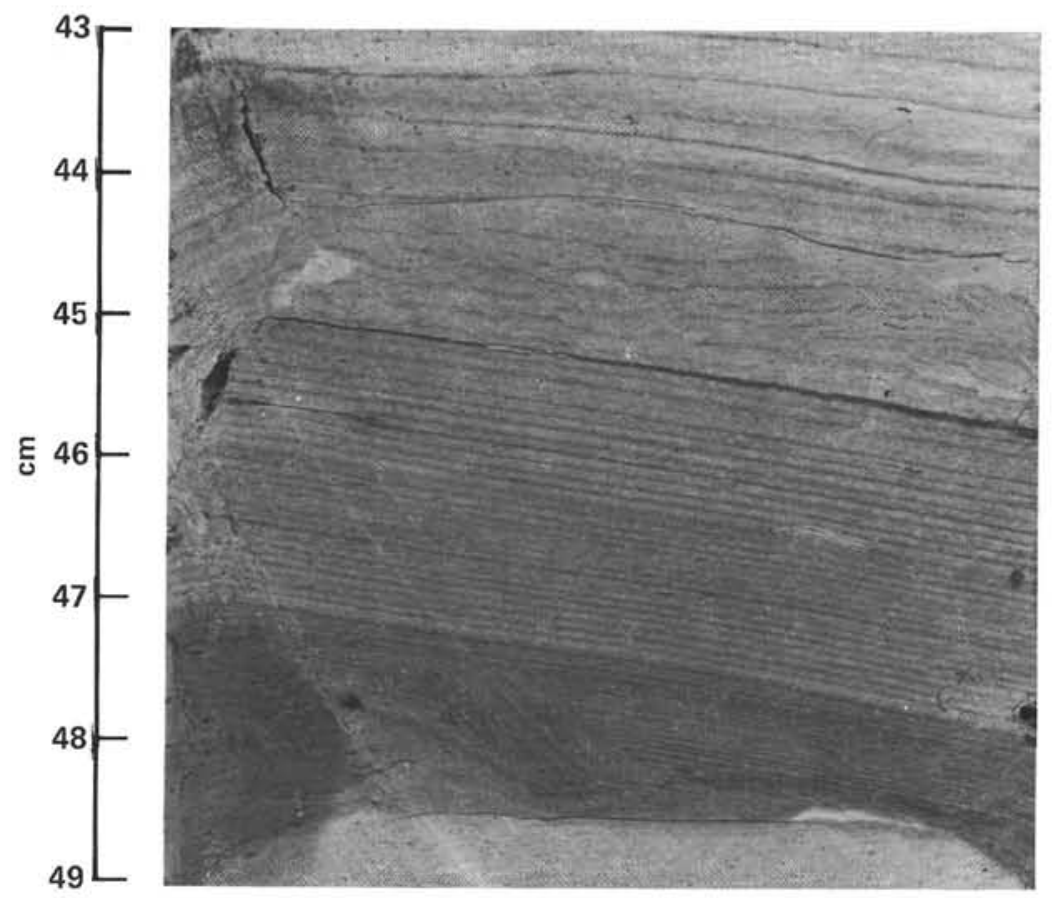

Plate 1. Submillimeter laminae within an oxidized sedimentary sequence $(551-5-1,43-49 \mathrm{~cm})$. 